\title{
Монгольские элементы в этнонимике и этнотопонимах долины Зеравшана (XV-XIX вв.)
}

\author{
Маликов Азим Маннонович, Университет Палацкого, Оломоуц, Чешская Республика; azimmal2018@gmail.com
}

В настоящей статье на основе данных письменных источников и архивных материалов анализируется роль монгольских компонентов в формировании родоплеменных названий и этнотопонимов долины Зеравшана с XV по XIX вв. В ходе исследования была выявлена динамика проникновения и распространения монгольских этнонимов на разных уровнях родоплеменной организации тюркоязычных племен региона. Вследствие миграций кочевых групп населения из степных районов в долину Зеравшана происходит обогащение родоплеменного состав населения и возрастание числа монгольских по происхождению названий, которые воспринимались местным населением как тюркские, узбекские, казахские и каракалпакские этнонимы. Общее число монгольских элементов в этнотопонимике долины Зеравшана возросло в связи с оседанием полукочевых родов в XVIII - начале XIX в. Монголизмы в этнотопонимах получили большее распространение в Самаркандской и Навоийской областях и меньше в Бухарском оазисе.

Ключевые слова: монголы, калмаки, чагатаи, Самарканд, Бухара, этнонимы, топонимы

\section{MONGOLIAN ELEMENTS IN THE ETHNONYMY AND ETHNOTOPONYMS OF THE ZERAVSHAN VALLEY (15-19 ${ }^{\text {TH }}$ CENTURIES)}

Azim Malikov, Palacky university Olomouc, Czech Republic; azimmal2018@gmail.com

This article, based on written sources and archival materials, analyzes the role of Mongolian components in the formation of tribal names and ethnotoponyms of the Zerafshan Valley from the $15^{\text {th }}$ to the $19^{\text {th }}$ centuries. The research revealed the dynamics of penetration and distribution of Mongolian ethnonyms at different levels of the tribal organization of Turkic-speaking tribes of the region. Numerous migrations of Turkic-Mongolian clans to the Zerafshan valley covered a long period, starting from the campaigns of Genghis Khan until the middle of the $18^{\text {th }}$ century. In the region, at different times, the perception of the boundaries of the Mongol community changed. If in the $13^{\text {th }}$ - early $14^{\text {th }}$ centuries under the name Mongol an ethnopolitical community was understood, as well as the inhabitants of the Mogholistan region, then later it designated the tribe and clan as part of individual tribes. If in the first waves of migration of Mongolian tribes to the oases of Central Asia their composition could include the main Mongolian clans, then in the following centuries their Turkification took place in the steppe regions and already Turkified tribes or alliances of tribes containing Turkic clans invaded and settled into the valleys.

As a result of the migrations of the nomadic population groups from the steppe regions to the Zerafshan valley, the tribal composition of the population became enriched and the number of Mongolian names, which were perceived by the local population as Turkic, Uzbek, Kazakh and Karakalpak ethnonyms, increased. Many Mongolian elements were included in the toponymy not by the Mongols themselves, but by Turkic or Turkified tribes. The total number of Mongolian elements in the ethnotoponymy of the Zerafshan Valley rose due to the settlement of semi-nomadic clans in the $18^{\text {th }}$ - early $19^{\text {th }}$ centuries. They became more widespread in the Samarkand and Navoi provinces and less common in the Bukhara oasis.

Keywords: Mongols, Kalmaks, Chagatai, Samarkand, Bukhara, ethnonyms, toponyms

Исследование по теме статьи было осуществлено благодаря гранту European Regional Development Fund — Project "Sinophone Borderlands: Interaction at the Edges" CZ.02.1.01/0.0/0.0/16_019/0000791. 


\section{Введение}

Оазисы Средней Азии ${ }^{1}$ на протяжении многих сотен лет находились на пути миграций полиэтнических групп населения с разными культурами. Имело место тесное взаимодействие, взаимовлияние оседлого и кочевого населения. В XIII-XIV вв. в регионе происходили сложные и широкомасштабные этномиграционные процессы, которые привели к усилению монгольского компонента в этническом составе и культуре номадов, находившихся в близких связях с оседлым населением. Тюрко-монгольские рода эпохи Чингис-хана, мигрировавшие в Среднюю Азию, растворились среди тюркоязычных народов в качестве их составных этнических компонентов и участвовали в формировании узбеков, казахов, киргизов, каракалпаков и др. [Номинханов 1962: 275]. Наследие эпохи монгольского правления важно для понимания концептуализаций этнической идентичности в Центральной Азии в последующий период [Biran 2004: 361].

Целью данной статьи является анализ монгольских компонентов в этнонимике и этнотопонимии долины Зеравшана. Основными задачами исследования являются выявление этапов и особенностей проникновения монгольских элементов в родоплеменную организацию кочевых племен долины Зеравшана, а также концептуализация монгольских самоназваний «могол», «чагатай», «калмык» в местных источниках.

Источником для исследования послужили публикации по топонимике долины Зеравшана, где располагаются два древнейших города Среднего Востока: Бухара и Самарканд. Регион был центром сложных этнокультурных процессов, которые оказывали определяющее влияние на историю населяющих его народов. По сравнению с другими оазисами Средней Азии в долине Зеравшана, где ныне располагаются Самаркандская, Навоийская и Бухарская области Узбекистана и часть территории Таджикистана, во второй половине XIX - начале XX в. было зафиксировано наибольшее число жителей, сохранивших родоплеменные названия.

Для долины Зеравшана издревле была характерна полиэтничность: здесь жили представители таких народов, как арабы, иранцы, таджики, евреи, казахи, каракалпаки, туркмены, узбеки, которые находились в тесном взаимодействии и взаимовлиянии друг с другом. В Среднезеравшанской долине находятся хорошие пастбища для круглогодичного выпаса скота, что в прошлом способствовало жизнедеятельности полукочевых групп населения [Ковалев, Ташбеков, Валиева 1962]. В нижней части долины Зеравшана располагается Бухарский оазис, в котором природно-географические условия сильно ограничивали проживание крупных кочевых племен. Другой особенностью было то, что в XVI-XIX вв. бухарские ханы вокруг столичной Бухары выделяли определенные участки земли для влиятельных представителей родоплеменных групп государства [Тураев 1989: 279-283], по имени или роду которых формировалось название ряда сел.

Хронологические рамки работы охватывают период от начала XV до конца XIX в. Этот период включает время, когда рассматриваемый регион был в составе государства Тимуридов, Бухарского ханства (периода Шибанидов, Джанидской или Тукай-Тимуридской династии), Бухарского эмирата (17561920). С 1868 по 1917 гг. долина Среднего Зеравшана находилась в составе Российской империи.

В топонимической стратиграфии долины Зеравшана при преобладании тюркского и персидского слоя монгольский пласт названий не является одним из основных. До настоящего времени актуальной остается проблема всестороннего изучения монгольского влияния на ономастику долины Зеравшана в целом. В статье мы будем использовать термин «тюрко-монгольские племена» ввиду сложного этнического состава соответствующих сущностей.

Исследование этнонимов дает возможность проследить пути этнических миграций, культурные и языковые контакты между народами. Однако в случае с монгольскими этнонимами ситуация является более сложной и запутанной. Как показывают источники, были десятки миграционных волн тюрко-монгольских родов, двигавшихся в оазисы Центральной Азии в разное время. Эти волны имели различный масштаб и численность. Поэтому возникают сложности в идентификации времени переселения родовых групп и их месторасположения. Надо различать этимологию самоназвания и меняющийся смысл, вкладываемый в его этническое содержание в зависимости от эпохи и социально-политического контекста.

\section{Обзор литературы и источников}

Вопросам тюрко-монгольских языковых связей посвящено значительное число работ. К настоящему времени в монголистике накоплен достаточно объемный эмпирический материал по этнонимике и топонимике.

${ }^{1}$ Под термином «Средняя Азия» мы подразумеваем современную территорию Кыргызстана, Таджикистана, Туркменистана и Узбекистана. 
Истоки тюрко-монгольских языковых связей и взаимовлияний уходят в древнюю эпоху [Санжеев, 1973; Щербак, 1997; Дыбо, 2007; Дыбо 2016]. Вопросы распространения монгольского языка и его влияния на тюркские языки Средней Азии были предметом исследования ряда специалистов, например, Н. Поппе, Ц. Номинханова, О. Серткая [Sertkaya 1992], Э. Чаки [Csáki 2006], М. Олмеза [Ölmez 2007] и др. Эти исследования были полезны для выявления заимствований из среднемонгольского языка в средневековые и современные тюркские языки.

Начало научному описанию родоплеменного состава населения долины Зеравшана положил Н. Ханыков [1843]. Во второй половине XIX в. российские лингвисты и востоковеды более подробно изучили родоплеменной состав населения долины Зеравшана [Гребенкин, 1872; Соболев, 1874; Хорошхин 1876]. В. Бартольдом [1963] был проведен глубокий анализ персидских и тюркских источников, касающийся истории монгольского нашествия в Средней Азии, его последствий, родоплеменной структуры населения. Вопросы происхождения, истории социально-политической организации тюркских и монгольских племен, их географическая локализация были освещены Н. Аристовым [1896]. Этнотопонимика Самаркандской области на основе письменных источников была проанализирована краеведом В. Вяткиным [1902].

Созданная при Российской академии наук комиссия по изучению родоплеменного состава России в 1921 г. собрала данные по этническому и родоплеменному составу сел долины среднего Зеравшана. Были записаны названия около 50 узбекских родов, делящихся на полтораста колен [Кун 1924: 356]. В настоящее время материалы хранятся в Центральном Государственном архиве Республики Узбекистан. Материалы исследований этнического состава населения Бухарской и Самаркандской областей в 1920-х годах были обобщены И. П. Магидовичем [1926].

В советский период формировались основы теории этноса, относящейся к примордиалистской школе, которая оказала влияние на методологию советской этнографии в последующие десятилетия. Характерной чертой исследований этнонимов советскими учеными было стремление установить преемственность и генетическую связь древних и современных этнонимов. Вместе с тем признавалось, что один и тот же этнос помимо этнонима-самоназвания (эндоэтнонима) мог иметь различные наименования, даваемые ему другими народами (экзоэтнонимы). Не исключалось, что по отношению к нескольким разным этническим группам мог использоваться один этноним [Бромлей 1983: 180].

Проблема монгольского компонента в этнической истории и этнотопонимике региона была частично освещена лишь в двух публикациях Ц. Д. Номинханова, который защитил кандидатскую диссертацию на тему «Монгольские административно-политические и военные термины XIII-XV вв., сохранившиеся в узбекском языке» [Муниев 1969: 4]. Им были проанализированы некоторые монгольские топонимы на территории Узбекистана [Номинханов 1962]. Исследования Номинханова были основаны на примордиальном подходе. Он не учитывал сложный и изменчивый характер родового состава монгольских племен, изменчивость восприятия этнонимов в зависимости от эпохи и социального контекста. Трансформация и изменение смыслового значения монгольских этнонимов «чагатай», «монгол - могол», «калмык» были предметом исследования ряда зарубежных, советских и постсоветских ученых [Благова 1972: 169-172; Крадин, Скрынникова 2006; Сухарева 1966; Кармышева 1976; Hesche, Hildebrandt, Thermann 1979; Manz 1989, 1992; Дремов 2013; Китинов 2018; Решетов 1983; Султанов 2017; Юдин 2001; de Rachewiltz 2019].

Канадский исследователь Джо Юп Ли на основе примордиального подхода анализировал материалы по концептуализации названия монголов в истории Центральной Евразии [Lee 2016]. Он считал, что между монгольскими племенами и тюркскими родами существовали четко различимые этнические границы, и полагал, что после походов Чингис-хана монгольские рода численно доминировали в степях Средней Азии [Lee 2018]. Эта точка зрения не объясняет сложный процесс тюркизации этих племен и не учитывает смешанный и сложносоставный характер монгольского населения Монгольской империи.

Различным аспектам изучения монголоязычных географических названий на территории Центральной Азии посвящены исследования российских, монгольских, казахских ученых: [Конкашпаев 1959; Мурзаев 1970, 1974; Номинханов 1962; Сагидолдагийн 1993] и др. Монгольские топонимы на территории Узбекистана в свое время были рассмотрены Ц.-Д. Номинхановым [1962: 257-275]. В изучении этнонимов долины Зеравшана особо следует отметить исследования Б. Кармышевой [1976]. Значительные исследования родового состава узбекских племен региона были проведены К. Шаниязовым [2001]. Родоплеменной состав узбеков и каракалпаков долины Зеравшана был освещен в публикациях Л. Толстовой [1961a, б]; Х. Ташева [1968], Х. Дониёрова [1968], М. Мирзаева [1969], А. Маликова [2018]. Во второй половине XX в. гораздо шире развиваются исследования топонимики Узбекистана, в том числе долины Зеравшана. Топонимике Узбекистана, в том числе долины Зеравшана была посвящена работа С. Караева [1991; Қораев 2005]. По топонимике города Бухары и Самарканда исследования прово- 
дила О. А. Сухарева [1958; 1966; 1976]. Сведения по средневековой топонимике долины Зеравшана содержатся в работах О. Д. Чехович [1965; Самаркандские документы 1974]. и др. У. Туйчиев защитил кандидатскую диссертацию по этнической топонимике долины Зеравшана [Туйчиев 1990б].

В годы независимости Узбекистана на основе теории этноса были освещены некоторые аспекты проблем этнотопонимики региона [Ўринбоев 1997; 2003; Бўриев 1997]. Топонимии Самарканда и Самаркандской области был посвящен ряд исследований филологов (см., например, [Туробов 2002]). По узбекским родам Самаркандской области были опубликована работа филолога Н. Бегалиева [2004]. В этих работах монгольский компонент в этнонимике и этнотопонимах региона отдельно не выделялся.

Современные исследования в рамках конструктивистского подхода позволяют по-новому подойти к проблеме концептуализации племени и этничности. Существует значительное число исследований по вопросам этничности, среди которых можно выделить публикации Ф. Барта [2006], Р. Дженкинса [Jenkins 1997], П. Бёрк [Burke 2003] и др. С учетом новых подходов появились публикации по истории социально-политической организации монгольских племен [Крадин, Скрынникова 2006; Wing 2016]. Фундаментальная работа А. М. Хазанова [2002] способствует пониманию сложного характера кочевых обществ Евразии.

Для реконструкции картины миграций разных этнических групп населения, этнического и родоплеменного состава населения важным источником являются этнотопонимы. Монголизмы встречаются в названиях этнических групп, наименованиях различных звеньев структурной организации тюркомонгольских племен и племенных союзов, в XV-XIX вв. проживавших на территории долины Зеравшана. В сравнении с предыдущими исследователями мы расширили документальную базу, используя источники XV—XIX вв., переписи 1872, 1887-1888 гг. и неопубликованные архивные материалы переписей 1921 г.

Ранние сведения о родоплеменном составе империи Чингис-хана и монгольских родах содержатся в монгольском источнике «Сокровенное сказание». После завоеваний Чингис-хана у мусульманских ученых открылись возможности для изучения монголов, их происхождения, языка и культуры. Лучшим примером является сочинение историка XIV в. Рашид ад-дина, где он собрал сведения по истории и устным преданиям тюрко-монгольских племен Монгольской империи, которые он получил от знатока монгольской истории Пуладчэнсяна и от чингизида Газан-хана. Помимо этого он использовал письменные монгольские источники [Бартольд 1963: 89, 92-93].

В сочинениях тимуридских авторов даются сведения о тюрко-монгольских племенах Средней Азии. Из них можно выделить летописцев Низам ад-Дина Шами, Шараф ад-Дина 'Али Йазди, автора «Му'из ал-ансаб», Абд ар-Раззака Самарканди, Захир ад-дина Бабура. Однако концептуализация термина «монгол» и его компонентов со стороны средневековых историков отличалась от современной, поэтому следует быть осторожным при интерпретации их сведений.

Сочинение неизвестного автора «Му“из ал-ансаб» содержит ценные сведения о тюрко-монгольских племенах, родоплеменном составе государственного аппарата тимуридской эпохи и др. Тимуридский историк, поэт, писатель Захир ад-дин Мухаммад Бабур (1483-1530) в своих мемуарах неоднократно упоминал различные племенные и этнические названия, включая монголизмы [Цэндмаа 2013].

Родоплеменной состав кочевых и полукочевых племен Среднеазиатского междуречья нашел отражение в сочинениях таких летописцев XVI-XIX вв., как Мухаммад Салиха (1455-1535), Хафиз Таныш Бухари, Абдурахман Тали, Мухаммад Амин Бухари, Абдалазим Сами [Malikov 2002: 617-623], а также в ряде списков 92 узбекских племен, составленных в долине Зеравшана и соседних областях [Malikov 2020: 515-532].

Сведения о родоплеменном составе узбеков и о тюркских родах долины Среднего Зеравшана содержатся в статистических материалах 1872 г. и 1887-1888 гг. [Соболев, 1874; Сборник материалов 1890]. Ценные сведения о взаимоотношениях узбеков-кунгратов и калмаков и их культуре содержатся в узбекском народном эпосе «Алпамыш», семь версий которого были составлены в долине Зеравшана [Маликов 2007].

В нашем исследовании монголизмы в этнотопонимах анализируются как источник по истории распространения этнонимов, их замещения другими этнонимами в зависимости от миграций, демографических изменений, политических событий и др. При интерпретации этнотопонимов следует иметь в виду, что изменения социальных связей и трансформация общества могут иметь следствием утрату памяти о значении названия и даже новое конструирование его значения. Для понимания сложного и длительного процесса проникновения монголизмов в этнонимику и этонотопонимику Средней Азии следует выявить особенности тюрко-монгольских связей и роль монгольского языка в регионе в рассматриваемый период. 


\section{Тюрко-монгольские связи и монгольский язык в Средней Азии}

Если допустить, что предками кара-китаев, появившихся в долине Зеравшана в середине XII века, были древние монголоязычные кидани [Дробышев 2010: 108; Vovin 2019: 162], то, вероятно, проникновение монголоязычных групп населения в Среднюю Азию имело место еще до походов Чингис-хана. Возможно, что термин «кидани» был политонимом, причем киданьские знатные рода включали в себя киданьские, монгольские и, возможно, китайские элементы [Biran 2005: 34, 36].

Более широкое распространение монгольского языка в Евразии начинается с началом походов Чингис-хана. Существовали летописи на монгольском языке в Ильханидском Иране. Вместе с тем надо отметить, что при организации государственной системы и письменного делопроизводства Монгольской империи играли немалую роль уйгуры [Бартольд 1963: 453 -454]. Как показывают документы, монгольский язык использовался восточными Чагатаидами (потомками второго сына Чингис-хана Чагатая) на территории Восточного Туркестана во второй половине XIV в. [Matsui 2008: 166, 171]. В эпоху Чагатайского улуса определенные группы родов Центральной Азии говорили на монгольском языке. По данным Тогана, в XIV в. на монгольском языке говорило племя дуглатов Восточного Туркестана [Togan 1962: 70]. Полагают, что монгольский язык сохранял некоторое значение в Мавераннахре ${ }^{2}$ до конца XV в. [Поппе 1938: 7; Номинханов 1962: 265].

Об определенном значении монгольского языка для народов Средней Азии свидетельствует многоязычный словарь «Мукаддимат аль Адаб» [Номинханов 1962: 264]. В поздней редакции от 1492 г. он представляет собой копию арабско-персидского словаря хорезмийского ученого аз-Замахшари (10751144), который был дополнен тюркским и монгольским языковым материалом [Поппе 1938; Saitô 2008]. Отметим, что в разных книгохранилищах мира существуют более 62 списков сочинения «Мукаддимат аль Адаб» разного объема, датируемых XIII-XVII вв., и лишь один включает в себя монгольскую часть [Islamov 2020: 3]. Заслуживает внимания тот факт, что именно этот список сочинения хранился в столице Бухарского ханства - Бухаре [Поппе 1938]. Как отмечали исследователи, в хронологическом плане литературный язык тюркского населения Средней Азии - чагатайский язык - состоит из разных слоев [Kincses-Nagy 1997: 143-144]. Поэтому следует избегать обобщения существующего материала и быть осторожным в выявлении заимствований. Монгольские слова в среднекипчакском языке были проанализированы исследователями (ср., например, [Csáki 2006]). Это такие слова, как хабурга, маглай, нукта, даруга, суюргал, нукер, курултай, макта, тухта и др. [Çiçеk 2015: 55, 56, 57, 61, 71, 76-78, 84-85], которые позже мы находим в лексике узбекского языка.

По мнению М. Олмеза, в чагатайском тюркском языке количество монгольских заимствований больше, чем в любом другом тюркском языке [Ölmez 2007: 229]. В источниках выявлены монгольские заимствования, которые охватывают различные сферы - части тела, военные и семейно-родственные термины и т. д. [там же: 229]. О. Серткая выделяет следующие семантические категории монгольских элементов в турецком языке: а) личные имена, б) фамилии, в) названия учреждений, г) титулы и должности, д) географические названия, е) монгольские суффиксы и ж) разное [Sertkaya 1987: 265-280]. Хотелось бы отметить, что монголизмы проникали и в персидский язык историографов Тимуридского государства. Например, Низам ад-дин Шами использовал такие слова, как аймак, баронгор, даруга, ёсо (яса), джета и др. [Шомий 1996: 506-507, 509].

В лексике узбекского языка встречаются монгольские элементы. На основе средневековых источников и словарей были выявлены монгольские слова в узбекском языке: ажарчи, аймок, айвоқчи, бақовул, бахадур, бовурчи, болиш, даруга, джавангар, джулду и др. [Чориев 2002: 8, 12, 17, 19, 21, 23, 37, 45, 46]. Следует отметить, что этимология и семантика этих слов вызывают споры среди исследователей. Учитывая разные по времени этапы миграции тюрко-монгольских кочевников в долину Зеравшана, можно утверждать, что обогащение монгольскими элементами местных тюркских диалектов и литературного языка происходило в разное время и с разной интенсивностью. Можно согласиться с Номинхановым, что из монголизмов в узбекском языке к началу XX в. доминировали общественно-политические термины, относящиеся к XIII-XIV вв. [Номинханов 1962: 274].

Несомненно, требуются более глубокие исследования монгольских заимствований в разных диалектах узбекского языка, особенно в кипчакских диалектах, значительная часть носителей которых имела более близкие связи с монголоязычными племенами и в более поздние периоды мигрировала из северных степных областей Центральной Азии. Особенности проникновения монголизмов в этнонимику кочевых и полукочевых племен Средней Азии могут быть выявлены прежде всего через понимание их социально-политической организации.

${ }^{2}$ Под термином Мавераннахр мы понимаем территорию между Амударьей и Сырдарьей. 


\section{Социально-политическая организация тюрко-монгольских племен в XIII-XV вB.}

Современные концепции родоплеменной организации способствуют пониманию особенностей монгольских компонентов в племенной структуре полукочевого населения долины Зеравшана. В источниках значение слова племя может быть совершенно разным и меняться со временем в зависимости от множества факторов, таких как территория, эпоха или происхождение автора [Zsidai 2018: 60]. Для поддержания племенных отношений имела значение генеалогия, которая узаконивала родство. Генеалогия не была статичной, а предоставляла идеологические средства группам кочевников для включения других родов в свою структуру. Другой особенностью племен была гибкость их структур [Wing 2016: 30-31]. Анализ генеалогических преданий тюркских племен и их организации в долине Зеравшана подтверждает открытость племенных границ и конструирование их генеалогий [Маликов 2018]. Таким образом, племена представляли собой политические единицы, которые определяли отношения социальной власти между кочевниками.

Монголы использовали ряд терминов для описания разных уровней социально-политической организации. Иерархия разных уровней представляла собой следующий ряд: урук (линидж) - обок (род) иргэн, улус (племя) [Крадин, Скрынникова 2006: 492]. В маркировке родства монголов большая роль принадлежала термину урук, который маркировал патрилинейное кровное родство [Скрынникова 2013: 29]. Монгольский термин для обозначения брачных отношений - анда-куда [Крадин, Скрынникова 2006: $88]$ - имеет аналог в современном узбекском языке в форме куда-анда. В узбекских диалектах долины Зеравшана и в письменной традиции для обозначения разных уровней племенной организации использовались термины тюркского, монгольского и арабского происхождения уруz, уруz-аймоқ, эл, элу уруд, улус, бов, туп, таифа, уй, қ̧авм, элат, фирка, джамоа [Маликов 2018: 45-46], причем использование этих терминов было изменчивым в зависимости от местной социально-политической организации и культурных традиций, которым следовали авторы исторических трудов.

В монгольских хрониках XIII в. упоминаются такие племена на территории современной Монголии, как кунгираты, баарины, баруласы, мангуты, арулады, генигесы, кераиты, меркиты, найманы, чиносы, баяуты и др. [Козин 1941: 83-161]. В период походов Чингис-хана (1219-1221) в Среднюю Азию мигрировали некоторые монгольские рода. Вероятно, эти племена раздробились и вошли в состав разных племен и народов. Чингис-хан и его потомки разрушили социальную организацию тюркоязычных племен Средней Азии, перетасовали их подразделения, вызвав значительные родоплеменные перегруппировки [Хазанов 2002: 246]. По мнению исследователей, эта политика привела к смешению тюркоязычного большинства с монгольским меньшинством и способствовала тюркизации монголов [Поляков 1980: 144-145; Султанов 2017: 76]. Хотя со временем монгольским осталось только название, все члены нового образования возводили свое происхождение к одному предку [Хазанов 2002: 246]. Состав «монгольских» войск включал тюркские элементы, которые монголы систематически мобилизовали в свою военную и экономическую машину [Golden 1992: 292]. Другие исследователи признают, что хотя монголы оставались политической и военной элитой, тюркские воины составляли большинство их войска [Аристов 1896: 306; Мау 2013: 227]. Трепавлов уточняет, что немногочисленные рода монголов в окружении кипчакских племен среднеазиатских степей были ассимилированы, но передали им свое название [Трепавлов 2002: 53]. При завоеваниях Чингизидов монгольские племена разделились на воинские части, которые были набраны либо из одного племени, либо из различных племен. В этих этнически разнообразных единицах названия племен были сокращены до названий кланов, а старые названия кланов часто исчезали [Golden 2000a: 24; Biran 2015: 153]. Существует также мнение, что распространение на тюркские рода некоторых монгольских этнонимов в качестве объединяющих самоназваний связано с тем, что эти тюркоязычные группы приняли название рода монгольского военачальника, возглавлявшего общую территориальную (административную и военную) единицу, в состав которой они входили [Жданко 1950: 119]. Эта версия поддерживается некоторыми современными исследователями, которые утверждают, что возвышение монголов создало новые коллективные идентичности с названиями, происходившими от имени командира, которому служили эти рода [Мау 2013: 227].

Административное деление Монгольской империи, имевшее место после 1260 г., заложило основы для четырех новых ханств и оказало влияние на формирование более новых идентичностей [Rossabi 2000: 44; Biran 2004: 354].

Следует отметить, что рода и племена с идентичными названиями оказывались в составе разных политических племенных объединений и народов. Как будет показано в дальнейшем, монгольские этнонимы использовались на разных уровнях родоплеменной организации тюрко-монгольских племен Средней Азии. 


\section{Термины «монгол» - «мугул» — «моголы» и их значения в источниках XIII-XIX вв.}

Важным этнонимом и политонимом, вокруг которого объединились разрозненные тюркомонгольские рода в ХІІІ в., было самоназвание «монгол», которое использовалось в нескольких значениях, а в последующие столетия претерпело трансформацию. Концепция множественной идентичности способствует пониманию взаимоотношений между различными идентичностями, при том что индивидуум может принадлежать к нескольким этническим общностям, с которыми он может идентифицировать себя в различных социальных ситуациях [Burke 2003: 195]. Кроме того, имеются отличия между процессами внешней и внутренней идентификации [Jenkins 1997]. Как отмечают исследователи, в реконструкции содержания понятия монголь конструктивным является принцип изучения границы общностей, названий племен и племенных союзов в историческом контексте средневековых сочинений [Крадин, Скрынникова 2006: 130]. Различают внешнюю и внутреннюю идентификацию, которые в определенных случаях могут быть взаимосвязаны и влиять друг на друга.

Впервые название «монгол» появляется для обозначения небольшой ветви племени Шивей, которое в IX в. проживало в долине реки Аргун. В X-XI вв. его представители мигрировали на запад и обосновались на склонах горы Бурхан-Халдун [de Rachewiltz 2019: 89]. На территории Монголии термин «монгол» мог выступать как этноним с двумя значениями: в значении как рода, так и племени, а кроме того, он мог использоваться как политоним [Крадин, Скрынникова 2006: 140]. Механизм идентификации у монголов средневековья демонстрирует наличие нескольких уровней. В многокомпонентном Монгольском улусе лидирующее положение занимал род монгол, однако в разных регионах и в разное время конструирование границ общности монголов значительно менялось [Скрынникова 2005: 56]. Термин «монгол» использовался в разных значениях: родовая группа, военная дружина; союз групп; конфедерация групп разного уровня (родов, племен, союзов), в которой имелась властная элита [Скрынникова 2005: 56-58].

В средневековых тюркских и персидских источниках встречается несколько видов обозначения монголов: мугул, могул, мугал. По мнению И. Рахевилца, использовать слово могол вместо слова монгол стали ввиду оскорбительного значения слова мунгул в уйгурском языке [de Rachewiltz 2019: 92]. На наш взгляд, проблема использования названия «могол» более сложна, потому что необходимо различать разные письменные и устные традиции использования этнонимов, но это потребует более глубоких сравнительных исследований.

Историк Рашид ад-дин (умер в 1318 г.) выделяет «народности, которых в настоящее время называют монголами, однако в начале их название не было таковым, потому что это название появилось спустя некоторое время после них» [Рашид ад-дин 1952: 77-78]. Рашид ад-дин также использовал категорию «коренных монголов», которые «разделились на две части» [Рашид ад-дин 1952: 78-79]. Он отмечал, что «ныне дошло до того, что монголами называют народы Хитая и Джурджэ, нянгасов, уйгуров, кипчаков, туркмен, карлуков, калачей, всех пленных и таджикские народности, которые выросли в среде монголов. И эта совокупность народов для своего величия и достоинства признает полезным называть себя монголами» [Рашид ад-дин 1952: 103]. Вероятно, обозначение «монгол» первоначально охватывало основные племена, подчиненные Чингис-хану. Оно исключало другие монгольские или тюркоязычные племена, такие как джалаир, ойрат, керейит и найман. Однако после обширных по территории монгольских завоеваний и роста престижности названия «монгол» сфера охвата этого термина расширилась. Существует также проблема неоднозначности монгольского происхождения родов, вовлеченных в походы Чингис-хана. Например, некоторые исследователи относят племена джалаиров и барласов к тюркским группам, а племена арлатов, сулдузов, мангытов, кунгратов, уйратов и бахринов к монгольским [Кармышева 1976: 172, 177, 179; Шониёзов 2001: 385-389]. Гибкость и близость этнических границ между тюркскими и монгольскими родами Монгольской империи нашли свое отражение в термине «тюрко-монголы», используемом в сочинении «Шуаб-и панджгана» («Пять родословий») Рашид ад-дина [Togan 1962: 68]. Этот термин в настоящее время используется и в академической науке [Manz 1989: 2].

Бартольд полагал, что победы Чингис-хана способствовали «развитию монгольского национального чувства» [Бартольд 1963: 90]. Он считал одним народом моголов и монголов [Бартольд 1964: 544]. По мнению Россаби, распад Монгольской империи на четыре отдельных враждующих друг с другом ханства и изменение этнического состава войск по мере расширения империи и включения тюрков, персов в ее состав способствовало размыванию монгольской идентичности [Rossabi 2000: 44].

В. Юдин отличал монголов от могулов, которые сформировались как народ во второй половине XIII - первой половине XIV в. на территории Могулистана (современная территория Кыргызстана, юго-восточного Казахстана и Восточного Туркестана). Уже в это время они были тюркоязычным наро- 
дом [Юдин 2001: 105]. В состав могульских племен входили такие рода, как кераиты, канглы - бекчики, арканут//аркануды, сулдузы, доглаты, чорасы, курлагуты, карлуки, итарчи - барак - акбараки, бахрин - барины, калучи, улачи, алучи, арлаты, барласы, мекриты, балыкчи, татары, долины, туркаты, узбеки и др. [Юдин 2001: 115-116]. Среди них, как мы видим, не только монгольские племена эпохи Чингис-хана, но и местные рода: канглы, карлуки и др. [там же]. Таким образом, к XV в. родовой состав могулов отличался от монголов эпохи Чингис-хана. Кармышева, следуя выводам Юдина, однозначно относит большинство могульских племен к тюркским [Кармышева 1976: 206]. Этнограф Шаниязов считал, что в источниках монголы назывались мўнсул, а после тюркизации стало применяться название мувул [Шониёзов 2001: 384].

Таким образом, существуют разные трактовки термина «могол». Одни исследователи считают моголов конгломератом тюркских и монгольских племен, другие - сословием на службе у ханов Чагатаидов, третьи - этнической группой. Султанов полагал, что в начале XVI в. название «могол» относилось только к военному сословию общества [Султанов 1989: 209].

Некоторые крупные тюрко-монгольские племена в эпоху Тимуридов имели свои уделы — «или» и «улусы», которые они населяли. Среди кочевников Чагатайского улуса выделяют главные рода: джалаиры, барласы, каучины и орлаты [Номинханов 1962: 260]. Манц подчеркивает, что каучины были наследственным военным классом или группой без внутренней организации [Manz 1989: 163].

Номинханов отмечает два важных процесса, протекавших в Средней Азии: тюркизацию и исламизацию монголов [Номинханов 1962: 262-263]. Бухарские документы XIV в. фиксируют этноним «мугул», причем он упоминается вместе с тюркским именем, например, Юлкутлуг мугули [Чехович 1965: 184]. После распада Монгольской империи стали формироваться новые идентичности [Biran 2004: 357]. Номинханов полагал, что в XIV-XV в. появился новый термин «узбек-монголы» [Номинханов 1962: 262-263]. Термин «узбек» с XIV в. был одним из самоназваний жителей восточной части Улуса Джучи (Джучи - старший сын Чингис-хана), что отличало их от названия «чагатай», применявшегося к племенам Чагатайского улуса [Аристов 1896: 4201421]. В XIV — начале XV в. в тимуридских источниках термин «мугул» имел три значения: одно из племен; народ, в состав которого входили барины; союз мугул-узбеков [Му“изз ал-ансаб 2006:120-121, 152, 155].

Интересным источником для понимания разных вариантов интерпретации этнонима «могол» являются воспоминания тимурида Захир ад-дина Мухаммад Бабура (1483-1530) «Бабур-наме». Его отец Умар-шейх происходил из тюркизированного рода барлас, переселившегося в Мавераннахр в эпоху Чингис-хана. Мать Бабура была из чингизидов. В своих воспоминаниях Бабур употреблял термин «могол» (муугул) в нескольких значениях. Он использовал этот термин как в этническом смысле, так и в региональном, обозначая выходца из области Могол или Моголистан (исторический регион на территории современного Кыргызстана, юго-восточного Казахстана и Восточного Туркестана) [Бабур-наме 1958: 15], но себя Бабур к моголам не относил.

Как заметили исследователи, генеалогия, несмотря на ее фиктивность, может моделировать границы общности, которые были актуальны для определенного времени [Крадин, Скрынникова 2006: 131]. Историк Тимуридов Шараф ад-Дин Али Йазди, повествуя о генеалогии Тимуридов и Чингизидов, включил в их число мифические личности: Тюрк-хана, сына Иафета, а также братьев-близнецов Татар-хана и Мугул-хана - потомков Тюрк-хана. Согласно этой генеалогии, потомки Мугул-хана, т. е. монголы, являются ветвью тюрков [Lee 2016: 130]. Таким образом, согласно тимуридским официальным историографам история тюрков и монголов считалась тесно взаимосвязанной на генеалогическом уровне. Эта же легенда повторяется в источниках XVI-XVIII вв. [Тали 1959: 13]. В отличие от тимуридских традиций, пришедшая в начале XVI века к власти династия Шибанидов (1501-1599; потомки старшего сына Чингис-хана - Джучи) имела больше легитимных прав и генеалогических традиций для выстраивания более широких связей с царствовавшей в Мавераннахре прежде династией Чагатаидов. Например, историограф бухарского хана, шибанида Абдуллы-хана II (1557-1598), подчеркивал его кровные связи с правящим родом потомков Чагатай-хана в Моголистане, которые названы «могольскими хаканами» [Бухари 1983: 93-94]. Очевидно, что шибанидский историк использовал термин «моголы» для обозначения кочевых жителей области Моголистан. Кроме того, «могол» также означало отюреченных кочевников монголов, имевших этнографические особенности [Султанов 2017: 84]. В дальнейшем, с 1520-х гг., моголы были вытеснены из Моголистана узбеками, киргизами и казахами, а часть была ассимилирована [Акимушкин 2004: 244]. Название «могол» не встречается в списках 92 узбекских племен, составленных в XVI-XIX вв. [Султанов 1982], что, видимо, связано с тем, что они не входили в состав государства Абулхайр-хана (1429-1468).

В афганском культурно-географическом окружении наблюдаются ряд других типов концептуализации самоназвания «могол» и особенностей языка его носителей. Первый тип: монголоязычные моголы, гео- 
А. М. МАликов

графически изолированные от основного массива монголов [Лигети 1952: 102-103]. Язык моголов Гератской области Афганистана имел некоторые особенности, соответствующие монгольскому языку XIII-XIV вв. [Weiers 1972: 154], однако на него сильное влияние оказал персидский. Второй тип: моголы Гурского района говорили на диалекте фарси, а у моголов в Меймене и Каттагане доминировал пушту [Кисляков 1973: 138]. Третий тип: в северо-восточном Афганистане (Бадахшане) жили группы тюркоязычных моголов, которые, однако, использовали различные идентичности: тюрк, узбек и могол. Эти идентичности носили взаимодополняющий характер: первое служило для отличия его от таджиков, второе - для выражения культурной общности с узбеками, а третье - для обозначения этнического происхождения [Hesche, Hildebrandt, Thermann 1979: 177]. Предполагают, что тюркоязычные моголы Бадахшана могли быть переселенцами из Могулистана, мигрировавшими в XVI в. [Hesche, Hildebrandt, Thermann 1979: 177-178].

На территории современного южного Узбекистана и Таджикистана моголы (мугул) были разнородны. Одни группы отличали себя от тюрков и узбеков, однако они, как и моголы Афганского Бадахшана, говорили на чагатайском тюркском языке. В культурном отношении они были близки к тюркам и карлукам [Кармышева 1976: 85]. В Кулябе были записаны следующие их родовые названия: али-могол, яккамогол, бозчи-могол, анархур, комурхур, черчи-могол, тубаки и отранчи [Кармышева 1976: 85].

Российские авторы второй половины ХIX в. трактуют род мугул (могул, могол) Самаркандской области как часть узбеков [Сборник материалов 1890: 139], а в устной традиции могол считался родом в составе различных подродов узбекского племени юз [Маликов 2018: 168]. Кармышева отмечала вариации самоназвания «могол», например, название мугул использовалось на территории современного Южного Таджикистана, а термин могал, носители которого говорили на кипчакском диалекте узбекского языка, был распространен в Самаркандской области. Моголы этих территорий были выходцами из Моголистана [Кармышева 1976: 205-206]. Моголы долины Зеравшана делились на ряд подразделений: мирза мугал, сарт-мугал, увал и др. [Маликов 2018].

Таким образом, термин могул продолжал использоваться как самоназвание в восточной части Чагатаидского улуса и имел более узкие локальные значения по сравнению с эпохой Монгольской империи. В XVI-XIX вв. название могул использовалось в определенном контексте, особенно для описания генеалогий правящих династий и отдельных племен.

\section{Монгольские компоненты в родоплеменных названиях XV-XIX вв.}

Среди монгольских этнонимов Средней Азии исследователи выделяли два уровня самоназваний. Первый уровень - названия, которые в разные периоды имели собирательное значение: «чагатай» и «калмак». Второй уровень - этнонимы отдельных племен [Номинханов 1962: 260]. Другим аспектом этого вопроса являются изменения, коснувшиеся содержания этих самоназваний. Происходившие трансформации были обусловлены рядом причин, к числу которых относились тюркизация и исламизация монгольских родов.

Во второй половине XIII - начале XIV в. произошла тюркизация монгольских племен в оазисах Средней Азии. Говоря о правителях Чагатайского улуса первой четверти XIV в., Ибн Баттута отмечает, что они говорили по-тюркски [Ибрагимов 1988: 99-100].

Другим важным фактором был процесс исламизации тюрко-монгольских родов, который занял продолжительный период. Еще в начале XIV в. в оазисах Среднеазиатского междуречья (Сурхандарья) часть кочевых родов сохраняли традиционные шаманистские верования, что выражалось, в частности, в обряде погребения, отличающемся от мусульманских обычаев [Пугаченкова 1967]. Нельзя сказать, что процессы лингвистической ассимиляции и исламизации были синхронными: так, например, в Афганистане монголы приняли ислам, но лишь в более поздний период стали переходить на персидский язык.

В источниках эпохи Тимуридов (1370-1507) в Мавераннахре упоминаются племена, мигрировавшие в эпоху Монгольской империи: арлаты, баявуты, барласы, дуглаты, джалаиры, дурбаты, йасавури, йисуты, каучины, кияты, кунграты, мугулы, мангыты, меркиты, найманы, нукузы, сулдузы, тайджуты, татары, уйраты, хитаи и др. [Му“изз ал-ансаб 2006: 117-120, 133, 135, 145, 164, 167]. Летописец Тимуридов Шараф ад-дин Али Йазди упоминает представителей следущих племен: барлас, джалаир, кунграт, йасури, сулдуз, кавчин, мангыт, арлат, меркит, бахрин, ктай, уйрат, дуглат и др. [Йазди 1997: 358-360]. Абдураззак Самарканди упоминает в государстве Тимуридов в Мавераннахре и Хорасане барласов, джалаиров, кавчинов, мугулов, найманов, сулдузов, арлатов и др. [Самарқандий 2008: 48, 64, 74, 97, 299, 338]. Б. Манц отмечает, что племена Чагатайского улуса различались по своей организационной структуре [Manz 1989: 32].

B XIV в. группу племен, расселившуюся на территории улуса Чагатая, в состав которого входила и территория Самаркандской области, называли чагатаями. Некоторые исследователи полагают, что тюр- 
кизированные монголы перестали использовать этноним «монгол» и перешли к новому самоназванию «чагатай» [Шониёзов 2001: 389]. Кармышева называла их «чагатайскими тюрками» [Кармышева 1976: 125]. Кроме того, использовались монгольские термины «джета» для обозначения жителей восточной части улуса, а для западной части, где преобладало оседлое население, применяли термин «караунас» [Султанов 2017: 74-92]. Точная этимология слова караунас неизвестна, по одной из гипотез оно могло означать «смешанные» [Jackson 2018: 91]. Политический раскол Чагатайского улуса на восточную и западную части в 1340-х гг. усилил использование термина «караунас» по отношению к западным племенным лидерам [Jackson 2018: 99]. Вообще, термин «караунас» применялся в разных значениях, больше в политическом и, возможно, в этническом смысле.

Чагатайцы играли в XIV-XV вв. большую роль в государствах Тимура и Тимуридов, а термин «чагатай» приобрел более широкий смысл. Благова считала, что на тюркоязычной почве складывалось вторичное значение слова чагатай, которое стало объединяющим для потомков Чагатая и его окружения, что подчеркивало привилегированность их положения в обществе. Постепенно стали формироваться черты оседлой культуры при сохранении внешних, церемониальных кочевых традиций [Благова 1972: 169-172]. Б. Манц выделяет более широкий круг факторов, обусловивших формирование чагатайской идентичности: формирование правящей элиты, следующей кочевому образу жизни и лояльной Чингизидам, а также проживание среди оседлого населения, следующего исламским традициям и религии [Manz 1992: 43].

B XIV-XV вв. наряду с идентичностью чагатай, в долине Зеравшана получили распространение новые для региона племенные объединения: барласы, арлаты, кунграты, найманы, кияты, минги, которые включили в свой состав прежние полукочевые тюркские рода [Благова 1972: 178].

В конце XIX в. в Бухарском эмирате существовала локальная идентичность чагатай - этим словом называли часть оседлого узбекского и таджикского населения [Кармышева 1976: 126]. Таким образом, из упомянутых в «Сокровенном сказании» и Рашид ад-дином более 40 племен в составе «коренных монголов» эпохи Чингис-хана, на территории долины Зеравшана и в прилегающих областях в источниках XIV-XV вв. фиксируются названия более 20 племен. Примечательно, что объединяющим наименованием для кочевых групп населения западной части улуса Чагатая становится название чагатай, а на востоке - мугул. Другие этнонимы применялись на уровне родов и племен.

C XV-XVI вв. в долине Зеравшана происходят сложные миграционные процессы, связанные с постоянным перемещением полукочевых племен и их взаимодействием с оседлым населением. B XVI в. происходит наплыв кочевых тюркоязычных племен, когда войска лидера полукочевых узбекских племен Шейбани-хана (1451-1510) завоевывают Среднеазиатское междуречье. По мнению Аристова, узбеки Шейбани-хана включали в себя племена, аналогичные казахским родам, однако среди узбеков оказалось больше «коренных монголов» и северо-восточных тюркских племен, к которым присоединились местные тюркские племена Мавераннахра [Аристов 1896: 421]. В результате сложных процессов слияния кочевых групп, смешения родов и принятия названий более могущественных на тот момент племен численность полукочевых родов в регионе возросла. В этот период усилилось распространение названия «узбек», которое первоначально объединяло часть тюрко-монгольских племен Улуса Джучи, а позже охватило и часть тюркоязычных групп населения Мавераннахра.

В составе войск Шейбани-хана в источниках упоминаются такие «узбекские племена», как мангыт, найман, кият, буркут, дурман, джалаир, сулдуз, нукуз, тама, татар, кунграт и др. [Солих 1989: 197]. Уже в начале XVI в. источники упоминают парные названия: кият-кунграт, мангыт-дурман, ушун-уйрат [Солих 1989: 201], что, возможно, свидетельствует о политических союзах и группах, которые традиционно заключали браки между собой. Актуальность монгольских преданий и самоназваний возросла с приходом к власти в Мавераннахре чингизидов-шибанидов. Во второй половине XVI в. на территории долины Зеравшана упоминаются такие «узбекские племена», как кераит, катаган, алчин, хитай, бахрин, джалаир, кунграт, дурман, кенагас и др. [Бухари 1983: 142-204]. В шибанидских источниках упоминаются следующие «узбекские племена»: катаган, найман, бахрин, кунграт, хитай, джалаир, дурман, кераит, чагатай, нукуз [Бухари 1983: 284—290], а также кият, аргун, калмак, чагатаи, аймак [Бухари 1989: 286-290]. Таким образом, по сравнению с тимуридским периодом к концу XVI в. наблюдается увеличение числа племен с монгольскими названиями в Среднеазиатском междуречье, что было связано с миграцией из степей Дешт-и-Кипчака. При Тимуридах были зафиксированы названия 20 тюрко-монгольских племен, объединяющим названием для которых было самоназвание чагатай. А в XVI в. их число превысило 22. Появились такие названия, как «калмак», «аймак», «буркут», «уйрат», а объединяющим названием стал этноним «узбек».

С приходом к власти Аштарханидов (1599-1756) в Мавераннахре усилилось влияние узбекских племен и родов, которые вели между собой борьбу за власть, земли и ресурсы. В XVII в. в источниках 
упоминаются следующие узбекские племена и тюркоязычные рода в долине Зеравшана с монгольской основой: найман, кунграт, дурман, джалаир, катаган [Термези 1971: 84-139]. Названия родоплеменных групп фиксируются в именах военачальников и чиновников Бухарского ханства. В источниках встречаются монголизмы: багрин, дурман, Аланкува, чагатайбеги, мангыт, буркут, джуют, дурман, кенегес, катаган, кунграт, кераит, могол, чагатай, чунак; имена: Джалма, Джагатай и др. [Тали 1959: 169-175].

В 1720-х гг. наблюдаются волны миграций кочевых племен из присырдарьинских регионов в оазисы Средней Азии, причем в число этих племен входили казахские и каракалпакские рода с монгольскими названиями [Толстова 1961a; Толстова 1961б; Маликов 2007]. В источниках XVI-XVIII вв. фиксируются более 24 монгольских этнонимов: «чагатай», «ногай», «калмак», «аймак» и др.

Этноним «калмак» представлен в этнонимии хакасов, киргизов, узбеков и каракалпаков. Он получил свое собирательное обозначение от тюркского глагола qalmaq 'оставаться', что обозначало имя народа, «оставшегося» вне ислама [DeWeese 1994: 364]. Номинханов однозначно трактовал калмаков как монгольскую народность, известную и под названием ойрат-монголов (западные монголы) [Номинханов 1962: 268]. ДеУис на основе анализа письменных источников пришел к выводу о том, что этноним «калмык» (или «калмак» у тюрков-мусульман) относился к западным монгольским племенам, известным также под собирательными обозначениями «ойрат»и «джунгар» [DeWeese 1994: 363-364]. По мнению Мирзо Улугбека (1394-1449), при правлении золотоордынского правителя Узбекхана (13121340) часть кочевых племен, приняв ислам, стали называться узбеками. Оставшаяся часть племен получила название «калмаки» — «оставшиеся» [Мирзо Улуғбек. 1994: 226]. Таким образом, здесь очевидна традиция противопоставления группы узбеков-мусульман группе неверных-калмаков. ДеУис считал, что враждебные отношения калмаков с тюрками-мусульманами продолжались с середины XV до конца XVIII в. и имели в том числе религиозный оттенок [DeWeese 1994: 363].

Тимуридский поэт Алишер Навои (1441-1501) в одной из своих поэм упоминает в качестве отдельных этнических групп на территории Среднеазиатского междуречья калмаков, муғул (моголов) и узбеков [Навоий 1993: 188]. При этом в сравнении с этнонимом «тюрк» самоназвание «могол» он упоминает редко. Калмаки входили в состав войска Шейбани-хана в начале XVI в. [Султанов 1982: 15]. Название «калмак» встречается во всех известных списках узбекских племен.

По мнению Мейендорфа, посетившего Бухару в 1820-х годах, большая часть бухарских калмыков происходила от орд Чингисхана, однако были и другие калмыки, которые являлись торгоутами из Поволжья. Первые из них говорили между собой по-тюркски, восприняли обычаи узбеков и жили в разных районах Бухарского ханства [Мейендорф 1975: 97-104]. О. Сухарева считала, что нужно различать два этнонима: «калмак» (название узбекского племени) и «калмык» (другое название монгольского племени ойратов) [Сухарева 1966: 134]. Поддерживая мнение О. Сухаревой, А. Алексеев полагал, что при дворе Аштарханидов служили калмаки и калмыки. «При этом калмаки входили в число племен “илатийа”, в то время как калмыки-джунгары поступали ко двору преимущественно в качестве военных рабов, из которых формировалась ханская гвардия» [Алексеев 2006: 168]. Калмаки были в составе родового войска (эльнавкар) бухарского эмира и участвовали в коронации [Андреев, Чехович 1972: 46 ].

У кыргызов отмечена этнографическая группа сарт-калмак. Причем первоначальное самоназвание их было кара-калмаки и лишь в конце ХІХ в. они стали называться сарт-калмаки [Жуковская 1980: 157]. Полагают, что эта группа калмаков выделяла себя из среды ойратов исходя из смешанных браков с узбеками, кыргызами, в связи с оседлым образом жизни и религиозной принадлежностью [Решетов 1983: 5]. Во второй половине XIX в. в Бухаре компактная группа калмаков населяла кварталы северо-западной части города и была таджикоязычной. Сухарева считала, что в Бухаре жили как знатные представители узбекского племени калмак, так и попавшие сюда в качестве рабов калмыки-ойроты [Сухарева 1966: 134].

По мнению Дремова, вероятнее всего, калмаками называли и различные рода западных монголовойратов, и группы монголоязычных кочевников восточного Дешт-и-Кипчака, не принявших ислам [Дремов 2013: 135]. Согласно предположению, слово «калмак» стало общим наименованием для идентификации немусульманских кочевников Центральной Азии, включая ойратов и другие этнические группы. Позже слово «калмак» закрепилось за ойратами [Китинов 2018: 277]. В узбекском народном эпосе «Алпамыш», семь версий которого были составлены на территории долины Зеравшана, кунгратыузбеки противопоставляются калмакам (кунғирот — қалмоқ) [Маликов 2007]. Видимо, название «калмак» в определенных контекстах могло использоваться для обозначения ойратов или немусульманского кочевого населения Средней Азии.

Процесс трансформации значения монгольских терминов в условиях оазисов Средней Азии ярко иллюстрируется на примере монгольского слова «аймак», которое первоначально означало 'род', ‘племя', ‘племенной союз' [Мурзаев 1984: 32]. К началу ХХ в. слово аймак в Узбекистане употреблялось местным узбекским и таджикским населением как в своем первоначальном значении, так и в новой интер- 
претации, обозначая коренное население данной местности [Кармышева 1980: 24-25]. Таким образом, слово аймак за многие века изменилось в значении и в среднеазиатском контексте стало использоваться в самых разных смыслах.

Во второй половине XIX в. бухарский историк Абдалазим Сами упоминает представителей узбекских племен Бухарского эмирата из следующих родов: мангыт, кытай, калмык, буркут, кара кунграт, ак мангыт, тук мангыт, кенегес, кытай-кипчаки (ктай-кипчаки), кунграты [Туйчиев 1990б]. Таким образом, в сочинении встречаются как названия племен эпохи Чингис-хана, так и рода с двойными - тюркомонгольскими - основами. В составе каракалпакских племен, переселившихся в XVIII в. в долину Зеравшана, также были рода ак-мангыт, кара-мангыт и тук-мангыт [Толстова 1961б: 46].

Согласно списку 92 узбекских племен, составленному Н. Ханыковым [1843], этнонимы Монгольской эпохи представлены от названия «мугул» до этнонимов позднего периода в виде «калмак». В книге «Насад Намаи-Узбекия», упоминались 30 родов с названиями эпохи Монгольской империи: Мангыт, Унгачит, Джалаир, Кунград, Найман, Уйрат, Калмак, Катаган, Кинягаз, Бутряк, Джуют, Чиль-джуют, Уймаут, Аралат, Киреит, Унгут, Муркут, Беркут, Куралас, Дурмен, Джуйрят, Шульдур, Бяхрин, Никюз, Мугул, Татар [Ханыков 1843: 61-64]. По данным Номинханова, на территории Узбекистана зафиксированы названия следующих монгольских племен и родов: джалаиры, барласы, каучины, кутчи, орлаты, мангат, кунград, кенегез, катаган, дурмен, барки (буркут), могол (монгуш), джерас (черазы), дуглат и хорлос [Номинханов 1962: 260].

Термин «татар» использовался в разных смыслах в зависимости от эпохи и культурногеографического контекста. Впервые этноним «татар» появился у тюркских и монгольских племен Центральной Азии в раннем средневековье [Golden 2000b: 370]. По мнению Голдена, «татар» было названием монгольской племенной группы [там же]. Другие исследователи полагают, что татарам изначально была присуща тюркская идентичность [Исхаков 2016: 435]. Данные источников свидетельствуют о том, что мусульманские и древнетюркские авторы применяли термин «татар» обобщенно к монголоязычным и тюркоязычным племенам Монголии [Кляшторный, Султанов 2009: 211].

Соседство монголов с татарами привело к появлению нового названия для общности монголо-татары [Крадин, Скрынникова 2006: 139]. По одной из версий, он представлял собой политоним, обозначавший двойной тюрко-монгольский состав населения [Исхаков 2016: 436]. Походы Чингис-хана и его потомков привели к более широкому распространению этнонима «татар» за пределами Монголии [Исхаков, Измайлов 2001: 85-86]. В XIV в. термин «татары» широко употреблялся только в Улусе Джучи, в то время как в других улусах использовались этнонимы «чагатай», «могол» [Измайлов 2011: 52]. Полагают, что в XIII-XIV вв. этноним «татар» обозначал военно-служилое сословие [Исхаков, Измайлов 2001: 42]. По мнению П. Голдена, с конца XIV в. в Золотой Орде политическое название «татар» стало надплеменным обозначением [Golden 1992: 317].

Предводитель кочевых узбеков чингизид Шейбани-хан (1451-1510) использовал термин «татар» в качестве названия племени или этнической группы [Şiban (Han.), Karasoy 1998: 201, 210, 220, 262]. В позднем средневековье самоназвание татар было известно как название народа и как название средневековых полукочевых родов. Следует различать обозначения разных групп татар в источниках. В источниках Бухарского эмирата поволжских татар называли булгарами, ногаями [Сухарева 1966: 180]. Кроме поволжских татар в долине Зеравшана жили представители узбекского племени татар. Название «татар» также использовалось как название одного из 92 узбекских племен [Султанов 1982: 43]. Этнотопонимы, содержащие элемент «татар», были отмечены в Джамбайском тумане Самаркандской и Бухарском, Вабкендском туманах Бухарской области [Маликов 2018: 173]. Таким образом, с XIV по XIX вв. наблюдается трансформация интерпретации названия и этнического содержания термина «татар».

В число исчезнувших до начала XX в. названий тюрко-монгольских родов в долине Зеравшана входили: сулдуз, йасури, дуглат, тайджиут. Из традиционного списка 92 узбекских племен в долине Зеравшана были представлены 50 племен. Некоторые из них имели разветвленную родоплеменную структуру. Они проживали в основном в восточных районах долины и в местности Мианкаль.

Анализ названий родовых групп узбекских, каракалпакских племен долины Зеравшана в XIX - начале XX в. показывает, что нередко использовались двойные или тройные названия. Одно из них было монгольским, а другое (или другие) - тюркским или иранским. Например, названия ак-мангыт, карамангыт, тук-мангыт включали тюркские компоненты ак, кара, тук. Также существовали аналогичные этнотопонимы [Маликов 2018]. Интересны названия с основой сарт (термин capm в определенных регионах обозначал оседлое население): сарт-мугол у узбеков-мугалов, сарт-хитай у узбеков-кипчаков.

Монгольский по происхождения этноним «уймавут» в XIX в. считался узбекским родом и подродом мангытов, кырков (малтаб), туяклов (вахтамагали) [Маликов 2018]. Род с аналогичным названием был у каракалпаков Бухарской области [Толстова 1961б: 46]. Этноним «баявут» был подродом узбеков-юзов 
(подрод карабчи) [Маликов 2018: 149]. Этноним «чалджиут» входил в состав узбеков-туяклов [Бегалиев 2004: 42] и узбеков-юзов [Маликов 2018: 180].

Благодаря переписям 1872 и 1887-1888 гг. мы имеем более широкую эмпирическую базу по названиям родов и племен разного уровня на территории долины Среднего Зеравшана, т. е. Самаркандской области. По данным Соболева, во второй половине XIX в. в долине Зеравшана преобладали узбеки, которые наряду с другими тюркоязычными жителями делились на 92 рода и племени, включая 19 тюркомонгольских родов с названиями эпохи Монгольской империи и более позднего времени: арлаты, барласы, бахрины, буркуты, дурманы, джалаиры, найманы, калмаки, каранайманы, кунграты, кераиты, кенагасы, кенагас-мангыты, кияты, мангыты, ногай-кипчакы, уйраты, чагатаи, чал-ногаи [Соболев 1874: 132 - 136]. В дополнение к этим названиям переписи 1887-1888 гг. зафиксировали также название «катаган» [Сборник материалов 1890: 85-193]. Рода катаган, кунграт были и у каракалпаков Бухарской области [Толстова 1961б: 46].

Если обобщить данные письменных источников и переписей, касающиеся монгольских названий на разных уровнях родоплеменной организации тюркоязычных племен долины Зеравшана в XIX в., то выясняется, что их число превышало 30.

\section{Особенности монгольского компонента в этнотопонимике Средней Азии и долины Зеравшана}

Актуальность исследования монголоязычной топонимии в отдельных регионах Евразии подчеркивалась исследователями, но при этом они отмечали, что такое изучение позволит в какой-то мере представить картину расселения и движения монгольских племен в прошлом [Очир-Гаряев 2010: 85]. Это утверждение верно для эпохи Монгольской империи. Если в первых волнах миграции монгольских племен в оазисы Средней Азии их состав мог включать основные монгольские рода и подрода, то в последующие века произошла их тюркизация в степных районах и в долины проникали и оседали уже тюркизированные племена или союзы племен, включавшие тюркские рода.

Упоминаемые Рашид ад-Дином монгольские и тюркские племена оставили след в современных топонимах Средней Азии и Ирана. По мнению Э. Мурзаева, в Средней Азии монгольская топонимика представлена слабо. Она относится прежде всего к Киргизии и частично Казахстану [Мурзаев 1974: 214]. Следует отличать топонимы, которые интерпретируются на основе как тюркской, так и монгольской лексики. В этом случае невозможно установить монгольское происхождение географических названий, они первоначально могли быть и тюркскими [Мурзаев 1974: 261]. Возникали топонимы гибридные, тюрко-монгольские. Существуют также топонимы монгольские, не имеющие параллелей в тюркских языках [Мурзаев 1974: 262]. По мнению некоторых исследователей, топонимы монголоязычного происхождения угадываются по грамматическим показателям -m, -ma, -maй, -meй, -mуй, -дай, -дей [ОчирГаряев, 2010: 89].

Топонимы монгольского происхождения на территории Казахстана включают в себя топонимы, образованные от: а) географических терминов; б) восхваляющих эпитетов; в) этнонимов); г) антропонимов (Жошы) [Сагидолдагийн 1993]. Исследователи отмечали, что в топонимии оазисов Средней Азии (на примере Джизака) многие монгольские основы были занесены в топонимию не самими монголами, а тюрками, заимствовавшими эти слова. Анализ топонимов с монгольскими элементами показывает, что большинство из них утратили свои дотопонимические значения [Закиров 1991].

Как заметили исследователи, от 10 до 30\% названий населенных пунктов Узбекистана составляют этнотопонимы, причем наибольший процент их представлен в долине Зеравшана [Караев 1991: 55]. В рассматриваемый период в долине Зеравшана были распространены топонимы согдийского, тюркского, персидского, монгольского и арабского происхождения. В Бухарской части, в отличие от Самаркандского оазиса, древние топонимы были представлены значительным числом названий. По наблюдениям исследователей, тюрко-монгольский пласт топонимики преобладал на востоке долины - в Булунгуре [Туйчиев 1990б: 69]. В Булунгурском тумане Самаркандской области доля этнотопонимов доходит до 80\%, [Туйчиев 1990a: 6, 11], причем многие из них относятся к узбекским или каракалпакским племенам.

Монголизмы в топонимии Узбекистана были выявлены Д. Номинхановым [1962]. Наибольшая их плотность отмечается в долине Зеравшана и Кашкадарьи [Мурзаев 1974: 259-260]. Номинханов отмечает узбекские кишлаки долины Зеравшана, носящие монгольские родоплеменные названия: Дурмен, Кунград, Могол, Джалаир, Катаган, Мангыт, Буркут, Чигатай, Кенегез, Каучин, Барлас, Арлат (Алат), Чакар, Уйрат, Турбат и др. Общее число таких сел на территории Узбекистана насчитывало 136, из которых 66 находилось в долине Зеравшана [Номинханов 1962: 273-274]. По нашим данным, число киш- 
лаков с названиями тюрко-монгольских племен эпохи Монгольской империи в долине Зеравшана превышает 100.

C XIV в. в долине Зеравшана число топонимов, связанных с родоплеменными названиями, возрастает, что было связано с оседанием кочевых групп. Анализ топонимов долины Зеравшана, имеющих монгольское происхождение, показывает, что они подверглись фонетической адаптации со стороны узбекского языка. В топонимике долины Зеравшана в XIV-XV вв. встречается ряд монгольских названий, в числе которых были названия родоплеменных объединений и племен [Буриев 1997].

В эпоху Шейбанидов (1500-1599) в долине Зеравшана существовали такие топонимы тюрко-монгольского происхождения, как Караунас, Айтаган и др. [Самаркандские документы 1974: 346, 353, 358]. Одним из известных монгольских племен были кияты. Кишлак с названием Кият упоминается в документах XV-XVI вв. на территории Самаркандской области [Самаркандские документы 1974: 443] и Бухарском оазисе [Населенные пункты 2001: 79-80].

В эпоху Аштарханидов в долине Зеравшана встречались монголизмы в этнотопонимах — например, Ходжа Барин, Чагатай [Вяткин 1902: 55-63]. В последующие периоды некоторые этнотопонимы сменились другими названиями.

Изучение данных топонимики показывает, что в XVIII - первой половине XIX в. на территории долины Зеравшана и прилегающих территориях происходит активный процесс оседания кочевников. В ряде районов целые родовые группы или группы родственных родов селились компактно, образуя одно или ряд соседних сел.

Из наиболее многочисленных групп узбеков с родовой идентификацией можно назвать мангытов, кунгратов, кипчаков, дурменов и др. Довольно большое число сел Бухарского оазиса Навоийской области носили названия таких тюрко-монгольских племен, как Бахрин (более 14 названий), Дурман (более 10), Катаган (более 11), Кунграт (более 10), Найман (10) [Населенные пункты 2001: 29-113]. В Бухарском оазисе отмечены ряд сел с названиями Мугул [Населенные пункты 2001: 98]. Существует более 8 этнотопонимов с основой мугул в разных районах Самаркандской и Бухарской областей [Ўринбоев 2003: 121-122; Туйчиев 1990а: 17-18]. В Пенджикентском районе вдоль реки Зеравшан имеются кишлаки Мугулаки боло (боло — «верхний») и Мугулаки поён (поён - «нижний»), со второй персидской основой [Дадабаева 2011: 83].

В долине Среднего Зеравшана оседали целые родовые группы, что видно в названиях сел. В эпоху Бухарского эмирата встречались монголизмы в этнотопонимах: Катаган, Чагатай, Найман-тепа [Вяткин 1902: 63 - 69]. Существуют более 10 этнотопонимов Чигатай в Самаркандской, Навоийской и Бухарской областях [Ўринбоев 2003, 205; Туйчиев 1990а, 16; Маликов 2018: 179]. Более семи этнотопонимов Калмак, Калмакон были отмечены в Самаркандской и Бухарской областях [Маликов 2018]. Вместе с тем, необходимо учитывать и местные особенности: например, топоним Нугай-ата в Самаркандской области не был связан с ногаями, а происходил от имени местного святого суфия Мухаммадяр Нугай-ата (умер в 1533 г.), который был здесь похоронен [Фитрат 2000: 35].

Можно констатировать, что рода, упоминаемые как названия подразделений кунгратов, встречаются в виде названий сел Самаркандской области. Например, отмечены следующие названия, встречающиеся в топонимике Самаркандской области: Мовлуш в Акдарьинском тумане; Мерган в Самаркандском тумане; Узун в Тайлакском, Пахтачийском и Ургутском туманах; Канджигали в Иштиханском тумане; Коракунгирот в Булунгурском тумане [Ўринбоев 2003: 108-256]. Видимо, в регионе происходило оседание целых родовых подразделений кунгратов.

На случаи возникновения этнотопонимов с племенными названиями, по всей видимости, могли оказывать влияние два фактора. Первый: если в селе оседали представители разных родов, тогда в выборе названия они приходили к компромиссу — например, делая выбор в пользу объединяющего племенного названия или же в пользу того рода, который был ближе к власти. Второй фактор: выбирали наиболее престижное название рода или племени - название, которое имело высокий политический и социальный статус в государстве (кунграт, бахрин, мангыт и др.).

Из тюрко-монгольских этнотопонимов в долине Зеравшана в XIX - начале XX в. встречаются более 50 названий. Наиболее распространенными были следующие названия: арлат (алат), барлас, бахрин (этнотопонимы Бахрин, Баринча, Бахринбаёт), буркут, джалаир, дурман, катаган, кунграт (племя кунграт зафиксировано в составе узбеков и каракалпаков), куралас, мангыт, мугул (могул, могол), найман, нугай, сулдуз, уймавут, уйрат, ширин и др. [Маликов 2018]. В городе Бухаре были кварталы Дурман, Катаган, Калмокон [Сухарева 1976: 128, 129, 236]. Эти названия находят параллели в других регионах Евразии, например, в Крыму, где среди тюрко-монгольских этнонимов чаще других встречаются такие названия: кунграт, кият, найман, кенегес, ойрат и др. [Бушаков 1991: 70-148]. 
Таким образом, возникновение монгольских элементов в этнотопонимике долины Зеравшана было связано с оседанием кочевых родов в разные исторические периоды. Собранные материалы выявляют как собственно монгольские основы названий, подвергшихся влиянию местных тюркских диалектов, так и гибридные названия, сочетавшие монгольскую основу с тюркской или персидской. В Бухарском оазисе влияние персидского языка ощущалось сильнее, чем в Самаркандской области, где число тюркомонгольских этнотопонимов было больше.

\section{Заключение}

В историко-географическом плане долина Зеравшана имела свои особенности, которые предопределили степень проникновения кочевых племен и их взаимодействие с оседлым населением. В Самаркандском оазисе находились хорошие пастбища для выпаса скота, что способствовало жизнедеятельности полукочевых групп населения. В долине нижнего Зеравшана - Бухарском оазисе - были другие условия, там преобладало оседлоземледельческое население.

Миграции тюрко-монгольских родов (а позже - и тюркизированных монгольских племен) в долину Зеравшана охватывали продолжительный период, начиная с походов Чингис-хана и до середины XVIII в. Учитывая разные по времени этапы миграции тюрко-монгольских кочевников в долину Зеравшана, можно утверждать, что обогащение монгольскими элементами местных тюркских диалектов и тюркского литературного языка происходило в разное время и с разной интенсивностью. Вероятно, что монгольский язык окончательно потерял свое значение в Мавераннахре к XVI в.

В регионе в разное время менялось конструирование границ общности монголов, что было связано с политическим фактором. Формирование после 1260-х гг. четырех отдельных тюрко-монгольских ханств оказало влияние на становление новых форм самоназваний: «чагатай», «могол» и др. Если в XIII - начале XIV в. под названием «монгол» понималась этнополитическая общность, а также жители области Моголистан, то позже оно обозначало племя, а также род в составе отдельных племен. Объединяющим названием для кочевых групп населения западной части улуса Чагатая становится название «чагатай», а на востоке - «мугул».

На территории долины Зеравшана и в прилегающих областях в источниках XIV-XV вв. фиксируются названия более 20 тюрко-монгольских племен, для которых надплеменным объединяющим названием был термин «чагатай». C XIV по XIX в. происходила трансформация этого названия. После XVI в. оно приобрело более локальный характер, обозначая представителей оседлой культуры в отдельных регионах. По сравнению с тимуридским периодом, к концу XVI в. наблюдается увеличение числа племен с монгольскими названиями в Среднеазиатском междуречье, что было связано с миграцией из степей Дешт-и-Кипчака. C XVI в. в Мавераннахре фиксируется рост числа тюрко-монгольских племен, для которых объединяющим названием был этноним «узбек», впервые получивший распространение в Золотой Орде и в государстве Абулхайр-хана.

Монгольские этнонимы использовались на разных уровнях родоплеменной организации тюркомонгольских племен Средней Азии. К XVIII-XIX вв. в долине Зеравшана в источниках фиксируются двойные и тройные названия тюрко-монгольских родов, которые включали в себя тюркские, монгольские и иранские элементы.

Этноним «калмак», обозначавший в XV в. западных монголов, к XVIII в. приобрел несколько значений. С одной стороны, различались два этнонима: «калмак» (название узбекского племени) и «калмык» (другое название монгольского племени ойратов). А с другой стороны, название «калмак» в определенных контекстах могло использоваться для обозначения ойратов или немусульманского кочевого населения Средней Азии.

Исследование монголоязычной топонимии в долине Зеравшана позволяет получить представление о расселении и движении монгольских племен в эпоху Монгольской империи. Если в первых волнах миграции монгольских племен в оазисы Средней Азии они могли включать в свой состав основные монгольские рода и подрода, то в последующие века произошла их тюркизация в степных районах, и в долины проникали и оседали уже тюркизированные племена или союзы племен, содержавшие тюркские рода.

Из монгольских этнотопонимов в долине Зеравшана в XIX - начале XX в. встречаются более 100 названий. Наиболее распространенными были следующие названия: арлат (алат), барлас, бахрин, буркут, джалаир, дурман, катаган, кунграт (племя кунграт зафиксировано в составе узбеков и каракалпаков), куралас, мангыт, мугул (могул, могол), найман, сулдуз, уймавут, уйрат и др.

Особенность Бухарского оазиса заключалась в том, что в XVI-XIX вв. ханы вокруг столичной Бухары выделяли определенные участки земли для влиятельных представителей родоплеменных групп государства, по имени или роду которых формировались названия ряда сел. Из тюрко-монгольских этно- 
попонимов Бухарского оазиса преобладали названия таких племен, как бахрин, дурман, катаган, кунграт, найман, мугул, чагатай, калмак, однако, в отличие от Самаркандского оазиса, большая часть этих сел была населена традиционным оседлым населением.

Изучение данных топонимики показывает, что в XVIII - первой половине XIX в. на территории долины Среднего Зеравшана и прилегающих территориях происходит активный процесс оседания кочевников, появляются села с тюрко-монгольскими названиями. По нашим данным, количество сел с названиями тюрко-монгольских племен эпохи Монгольской империи в долине Зеравшана превышает 100. Наибольшее их число приходится на восточную часть долины Зеравшана, причем многие из них относятся к узбекским или каракалпакским племенам. Многие монгольские основы были занесены в топонимию не самими монголами, а тюркскими или тюркизированными родами.

\section{Литература}

Акимушкин $2004-$ Акимушкин О. Ф. Моголистан, моголы и киргизы в первой половине XVI в. (Заметка по политической истории региона) // Средневековый Иран. Культура, история, филология. СПб., 2004. С. $242-244$. \{Akimushkin O. F. Mogolistan, Mughals and Kyrgyz in the first half of the $16^{\text {th }}$ century (Note on the political history of the region) // Medieval Iran. Culture, history, philology. St. Petersburg, 2004. P. 242-244.\}

Алексеев 2006 - Алексеев A. K. Политическая история Тукай-Тимуридов: по материалам персидского исторического сочинения Бахр ал-асрар. СПб., 2006. \{Alekseev A. K. The political history of the Tukai-Timurids: based on the materials of the Persian historical work Bahr al-asrar. St. Petersburg, 2006.\}

Андреев, Чехович 1972 - Андреев М. С., Чехович О. Д. Арк (кремль) Бухары в конце XIX - начале XX в. Душанбе, 1972. \{Andreev M. S., Chekhovich O. D. Ark (Kremlin) of Bukhara in the late $19^{\text {th }}-$ early $20^{\text {th }}$ centuries. Dushanbe, 1972.\}

Аристов 1896 - Аристов Н. А. Заметки об этническом составе тюркских племен и народностей и сведения об их численности // Живая старина. 1896. Год шестой, вып. III—IV. С. 277-456. \{Aristov N. A. Notes on the ethnic composition of Turkic tribes and nationalities and information on their numbers // Living antiquation. 1896. Sixth year, issue III-IV. P. 277-456.\}

Бабур-наме 1958 - Бабур-наме / Пер. М. А. Салье. Ташкент, 1958. \{Babur-name / Translated by M. A. Salie. Tashkent, 1958.\}

Барт $\Phi$. Введение // Этнические группы и социальные границы. Социальная организация культурных различий. Под ред. Фредрика Барта. М., 2006. С. 9 - 48. \{Bart F. Introduction // Ethnic groups and social boundaries. Social organization of cultural differences. Ed. Fredrik Barth. Moscow, 2006. P. $9-48$.

Бартольд 1963 - Бартольд В. В. Сочинения. Т. 1. М., 1963. \{Bartold V. V. Works. Vol. 1. Moscow, 1963.\}

Бартольд 1964 - Бартольд В. В. Сочинения. Т. 2. Ч. 2. М., 1964. \{Bartold V. V. Works. Vol. 2. Part. 2. Moscow, 1964.\}

Бегалиев 2004 - Бегалиев Н. Б. Ўзбек этнонимлари тарихидан. Самарканд, 2004. \{Begaliev N. B. From the history of Uzbek ethnonyms. Samarkand, 2004.\}

Благова 1972 - Благова Г. Ф. Тюркск. Чақатај - русск. Чагатай-/джагатай- (Опыт сравнительного изучения старого заимствования) // Тюркологический сборник. 1971. М., 1972. С. 167—205. \{Blagova G. F. Turkic Chaqataj Russian Chagatay- / jagatay- (Experience of comparative study of old borrowing) // Turkological collection. 1971. Moscow, 1972. P. 167-205.\}

Бромлей 1983 - Бромлей Ю. В. Очерки теории этноса. М., 1983. \{Bromley Y. V. Essays on the theory of ethnos. Moscow, 1983.\}

Бухари 1983 - Бухари Хафиз-и Таныши. Шараф-нама-йи шахи (Книга шахской славы). Ч. 1 / Пер. с перс., введ., примеч. и указ. М. Салахетдиновой. М., 1983. \{Bukhary Khafiz Tanish. Sharaf namayi shakhi. Book of the Shah's Glory. Part 1 / Translation from Persian, introduction, notes and pointers by M. Salakhetdinova. Moscow, 1983.\}

Бухари 1989 - Бухари Хафиз-и Таныии. Шараф-нама-йи шахи (Книга шахской славы). Ч. 2. Пер. с перс., введ., примеч. и указ. М. Салахетдиновой. М., 1989. \{Bukhary Khafiz Tanish. Sharaf namayi shakhi. Book of the Shah's Glory. Part 2. Translation from Persian, introduction, notes and pointers by M. Salakhetdinova. Moscow, 1989.\}

Бушаков 1991 - Бушаков В. А. Тюркская этноойконимия Крыма. Диссертация ... канд. филол. наук. М., 1991. \{Bushakov V. A. Turkic ethnooikonymy of Crimea. PhD. thesis. Moscow, 1991.\}

Бўриев 1997 - Бўриев O. Темурийлар даври ёзма манбаларида Марказий Осиё. Ташкент, 1997. \{Buriev O. Central Asia in written sources of the Timurid era. Tashkent, 1997.\}

Вяткин 1902 - Вяткин В. Л. Материалы к исторической географии Самаркандского вилаета // Справочная книжка Самаркандской области. 1902 год. Вып. VII. Самарканд, 1902. \{Viatkin V. L. Materials for the historical geography of the Samarkand region // Reference book of the Samarkand region. 1902 year. Issue VII. Samarkand, 1902.\}

Гребенкин 1872 - Гребенкин А. Д. Узбеки // Русский Туркестан. Вып. 2. СПб., 1872. \{Grebenkin A. D. The Uzbeks // Russian Turkestan. Issue 2. St. Petersburg, 1872.\} 
Дадабаева 2011 - Дадабаева М. К вопросу об этнонимах и этнотопонимах Северного Таджикистана // Ученые записки Худжандского государственного университета им. академика Б. Гафурова. Гуманитарные науки 2.2011. C. 76-89. \{Dadabaeva M. On the issue of ethnonyms and ethnotonyms of Northern Tajikistan // Scientific notes of the Khujand State University named after academician B. Gafurov. Humanities 2. 2011. P. 76-89.\}

Дониёров 1968 - Дониёров X. Ўзбек халқининг шажара ва шевалари. Ташкент, 1968. \{Doniyorov Kh. Genealogy and dialects of the Uzbek language. Tashkent, 1968.\}

Дремов 2013 - Дремов И. И. Калмаки улуса Джучи // Вестник Прикаспия: археология, история, этнология. 4. 2013. C. 126-137. \{Dremov I. I. Kalmaks of the Jochi ulus // Bulletin of the Caspian region: archeology, history, ethnology. 4. 2013. P. 126-137.\}

Дробышев 2010 - Дробышев Ю. И. Политика киданей в Центральной Азии // Общество и государство в Китае 40. 2010. C. 108-122. \{Drobyshev Yu. I. Khitan policy in Central Asia // Society and state in China 40. 2010. P. 108-122.\}

Дыбо 2007 - Дыбо А. В. Лингвистические контакты ранних тюрков. Лексический фонд: пратюркский период. M., 2007. \{Dybo A. V. Linguistic contacts of the early Turks. Lexical fund: pra-Turkic period. Moscow, 2007.\}

Дыбо 2016 - Дыбо А. В. К вопросу о пратюрко-монгольских контактах // Современные проблемы гуманитарных и социальных наук: Материалы международной научно-практической конференции, посвященной 25-летию Независимости Республики Казахстан. Астана, 2016. С. 247-255. \{Dybo A. V. On the issue of Pra-Turkic-Mongolian contacts // Modern problems of the humanities and social sciences: Materials of the international scientific-practical conference dedicated to the $25^{\text {th }}$ anniversary of the Independence of the Republic of Kazakhstan. Astana, 2016. P. 247-255.\}

Жданко 1950 - Жданко T. A. Очерки исторической этнографии каракалпаков М.—Л., 1950. \{Zhdanko T. A. Essays on the historical ethnography of Karakalpaks. Moscow — Leningrad, 1950.\}

Жуковская 1980 - Жуковская Н. Л. Иссык-кульские калмаки (сарт-калмаки) // Этнические процессы у национальных групп Средней Азии и Казахстана. М., 1980. С. 157-166. \{Zhukovskaya N. L. Issyk-Kul Kalmaks (SartKalmaks) // Ethnic processes among national groups of Central Asia and Kazakhstan. Moscow, 1980. P. 157-166.\}

Закиров 1991 - Закиров А. А. Топонимия Джизакской области Узбекской ССР. Автореферат дисс. ... канд. филолог. наук. М., 1991. \{Zakirov A. A. Toponymy of the Jizzakh region of the Uzbek SSR. PhD thesis. Moscow, 1991.\}

Ибрагимов 1988 - Ибрагимов Н. Ибн Баттута и его путешествия по Средней Азии. М., 1988. \{Ibragimov N. Ibn Battuta and his travels in Central Asia. Moscow, 1988.\}

Измайлов 2011 - Измайлов И. Л. Татары в империи Чингиз-хана и его наследников: триумф побежденных // Золотоордынское наследие, 2011. С. 38-55. \{Izmaylov I. L. Tatars in the empire of Genghis Khan and his heirs: triumph of the defeated // Golden Horde Heritage, 2011. Р. 38-55.\}

Исхаков, Измайлов 2001 - Исхаков Д. М., Измайлов И. М. Этнополитическая история татар в VI - первой четверти XV века // Татары. М., 2001. С. 41-161. \{Iskhakov D. M., Izmaylov I. M. Ethnopolitical history of the Tatars in the $6^{\text {th }}$ - the $1^{\text {st }}$ quarter of the $15^{\text {th }}$ century // Tatars. Moscow, 2001. P. 41-161.\}

Исхаков 2016 - Исхаков Д. М. Термин «татаро-монголы/монголо-татары»: понятие политическое или этническое? Опыт источникового и концептуального анализа // Золотоордынское обозрение. Т. 4. № 2 (2016). С. 420 - 442. \{Iskhakov D. M. The term "Tatar-Mongols/Mongol-Tatars": the political or the ethnic concept? The experience of source and conceptual analysis // Golden Horde Review. Vol. 4. No. 2 (2016). P. 420-442.\}

Китинов 2018 - Китинов Б. У. Калмак и ойраты: топоним в религиозной истории народов Центральной Азии // Вестник Российского университета дружбы народов. Серия: Всеобщая история 10.3. 2018. С. 270-281. \{Kitinov B. U. Kalmak and Oirats: a toponym in the religious history of the peoples of Central Asia // Bulletin of the Peoples' Friendship University of Russia. Series: General History 10.3. 2018. P. 270-281.\}

Караев 1991 - Караев С. К. Топонимия Узбекистана. Ташкент, 1991. \{Karaev S. K. Toponymy of Uzbekistan. Tashkent, 1991.\}

Кармышева 1976 - Кармышева Б. Х. Очерки этнической истории южных районов Таджикистана и Узбекистана. M., 1976. \{Karmysheva B. Kh. Essays on the ethnic history of the southern regions of Tajikistan and Uzbekistan. Moscow, 1976.\}

Кармышева 1980 - Кармышева Б. Х. «Кочевая степь» Мавераннахра и ее население в конце XIX - начале XX в. (по этнографическим данным) // Советская этнография. 1980. № 1. С. 45-56. \{Karmysheva B. Kh. The “nomadic steppe" of Maverannahr and its population at the end of the $19^{\text {th }}$ - beginning of the $20^{\text {th }}$ centuries. (according to ethnographic data) // Sovetskaya etnografiya (Soviet Ethnography). 1980. No. 1. P. 45-56.\}

Кисляков 1973 - Кисляков В. Н. Хазарейцы, аймаки, моголы // Советская этнография. № 4. 1973. С. 130 - 139. \{Kislyakov V. N. Hazaras, Aimaks, Moguls // Sovetskaya etnografiya (Soviet Ethnography). № 4. 1973. P. 130—139.\}

Кляшторный, Султанов 2009 - Кляшторный С. Г., Султанов Т. И. Государства и народы Евразийских степей. От древности к новому времени. СПб., 2009. \{Klyashtorniy S. G., Sultanov T. I. States and peoples of the Eurasian steppes. From antiquity to modern times. St. Petersburg, 2009.\}

Ковалев, Ташбеков, Валиева 1962 - Ковалев С., Ташбеков Э., Валиева Р. География сельского населения и сельских населенных пунктов Самаркандской и Бухарской областей. Ташкент, 1962. \{Kovalev S., Tashbekov E., Valieva R. Geography of rural population and rural settlements of Samarkand and Bukhara regions. Tashkent, 1962.\} 
Козин 1941 - Козин С.А. Сокровенное сказание. Монгольская хроника 1240 года. Т. 1. М.-Л., 1941. \{Kozin S. A. The Secret History. Mongolian chronicle of 1240. Vol. 1. Moscow - Leningrad, 1941.\}

Конкашпаев 1959 - Конкашпаев Г. К. Географические названия монгольского происхождения на территории Казахстана // Известия АН Казахской ССР, серия филология. Вып. І. Алма-Ата, 1959. С. 85-98. \{Konkashpaev G. K. Geographic names of Mongolian origin on the territory of Kazakhstan // News of the Academy of Sciences of the Kazakh SSR, philology series. Issue I. Alma-Ata, 1959. P. 85-98.\}

Қораев 2005 - Қораев C. Ўзбекистон вилоятлари топонимлари. Тошкент, 2005. \{Qoraev S. Toponyms of the regions of Uzbekistan. Tashkent, 2005.\}

Крадин, Скрынникова, 2006 - Крадин Н. Н., Скрынникова Т. Д. Империя Чингис-хана. М., 2006. \{Kradin N. H., Skrynnikova T. D. Empire of Genghis Khan. Moscow, 2006.\}

Кун 1924 - Кун В. Изучение этнического состава Туркестана // Новый Восток. Книга 6. M., 1924. \{Kun V. Study of the ethnic composition of Turkestan // New East. Book 6. Moscow, 1924.\}

Лигети 1954 - Лигети Л. О монгольских и тюркских языках и диалектах Афганистана // Acta Orientalia Academiae Scientiarum Hungaricae. 1954. C. 93-117. \{Ligeti L. On the Mongolian and Turkic languages and dialects of Afghanistan // Acta Orientalia Academiae Scientiarum Hungaricae. 1954. P. 93-117.\}

Магидович 1926 - Магидович И. Население // Материалы по районированию Средней Азии. Книга 1. Территория и население Бухары и Хивы. Часть 1. Бухара. Ташкент, 1926. \{Magidovich I. Population // Materials on the regionalization of Central Asia. Book 1. Territory and population of Bukhara and Khiva. Part 1. Bukhara. Tashkent, 1926.\}

Маликов 2007 - Маликов А. М. Узбеки группы кунграт долины Зерафшана в XIX — начале XX в. Самарканд, 2007. \{Malikov A. M. Uzbeks of the kungrat group of the Zerafshan valley in the $19^{\text {th }}$ - early $20^{\text {th }}$ centuries. Samarkand, 2007.\}

Маликов 2018 - Маликов А. М. Тюркские этнонимы и этнотопонимы долины Зерафшана (XVIII - начало XX в.). Ташкент, 2018. \{Malikov A. M. Turkic ethnonyms and ethnotonyms of the Zerafshan valley (XVIII - early XX centuries). Tashkent, 2018.\}

Материалы 1969 - Материалы по истории казахских ханств XV-XVIII веков (извлечения из персидских и тюркских сочинений). Алма-ата, 1969. \{Materials on the history of Kazakh khanates of the XV-XVIII centuries (extracts from Persian and Turkic writings). Alma-ata, 1969.

Мейендорф 1975 - Мейендорф Е.Ф. Путешествие из Оренбурга в Бухару. М., 1975. \{Meyendorf E. F. Travel from Orenburg to Bukhara. Moscow, 1975.\}

Мирзаев 1969 - Мирзаев M. М. Ўзбек тилининг Бухоро группа шевалари. Ташкент, 1969. \{Mirzaev M. M. Bukharan group of dialects of the Uzbek language. Tashkent, 1969.\}

Мирзо Улуғбек 1994 - Мирзо Улувбек. Тўрт улус тарихи / Форс тилидан Б. Ахмедов, Н. Норқулов, М. Хасанийлар таржимаси. Ташкент, 1994. \{Mirzo Ulugbek. The history of four uluses / Translated from Persian by B. Ahmedov, N. Norkulov, M. Khasaniy. Tashkent, 1994. $\}$

Му‘ изз ал-ансаб 2006 - Му‘изз ал-ансаб (Прославляющее генеалогии) / Введение, перевод с персидского, примечания, подготовка факсимиле к изданию Ш. Х. Вахидова // История Казахстана в персидских источниках. Т. 3. Алматы, 2006. С. 117-119. \{Mu'izz al-ansab (Glorifying genealogy) / Introduction, translation from Persian, notes, preparation of facsimile for publication by Sh. Kh. Vakhidov // History of Kazakhstan in Persian sources. Vol. 3. Almaty, 2006. P. 117-119.\}

Муниев 1969 - Муниев Б. Д. 70-летие доктора филологии Ц.-Д. Номинханова // Ученые записки. Вып. 7. Серия филологическая. Элиста, 1969. С. 3-8. \{Muniev B. D. $70^{\text {th }}$ anniversary of Doctor of Philology Ts.-D. Nominhanov // Scientific notes. Issue 7. Philological series. Elista, 1969. P. 3-8. \}

Мурзаев 1974 - Мурзаев Э. М. Очерки топонимики. М., 1974. \{Murzaev E. M. Essays on toponymy. Moscow, 1974.\}

Мурзаев 1984 - Мурзаев Э. М. Словарь народных географических терминов. М., 1984. \{Murzaev E. M. Dictionary of folk geographic terms. Moscow, 1984.\}

Навоий 1993 - Навоий Алишер. Мукаммал асарлар тўплами. 20 томлик. 11-том. Тошкент, 1993. \{Navoi A. Complete Works in 20 volumes. Vol. 11. Tashkent, 1993.\}

Населенные пункты 2001 - Населенные пункты Бухарского эмирата (конец XIX - начало XX в.). Материалы к исторической географии Средней Азии. Ташкент, 2001. \{Settlements of the Bukhara Emirate (late XIX - early XX centuries). Materials on the historical geography of Central Asia. Tashkent, 2001.\}

Номинханов 1962 - Номинханов Ц. Д. Монгольские элементы в этнонимике и топонимике Узбекской ССР // Записки Калмыцкого научно-исследовательского института языка, литературы и истории. Вып. 2. Элиста, 1962. C. 257-275. \{Nominhanov Ts. D. Mongolian elements in ethnonymy and toponymy of the Uzbek SSR // Notes of the Kalmyk Research Institute of Language, Literature and History. Issue 2. Elista, 1962. P. 257-275.\}

Очир-Гаряев 2010 - Очир-Гаряев В. Э. Миграции монгольских племен по данным топонимии // Гуманитарный вектор. Серия: Педагогика, психология 3. 2010. С. 84-91. \{Ochir-Gariaev V. E. Migration of Mongolian tribes according to toponymy data // Humanitarian vector. Series: Pedagogy, Psychology 3. 2010. P. 84—91.\} 
Поляков 1980 - Поляков С. П. Историческая этнография Средней Азии и Казахстана. М., 1980. \{Polyakov S. P. Historical ethnography of Central Asia and Kazakhstan. Moscow, 1980.\}

Поппе 1938 - Попnе Н. Н. Монгольский словарь Мукаддимат ал-Адаб. Часть I-II // Труды Института востоковедения АН СССР. Т. XIV. М.-Л., 1938. \{Poppe N. N. Mongolian dictionary Mukaddimat al-Adab. Part I-II // Proceedings of the Institute of Oriental Studies of the USSR Academy of Sciences. T. XIV. Moscow — Leningrad, 1938.\}

Пугаченкова 1967 - Пугаченкова Г. А. Погребение монгольского времени в Халчаяне // Советская археология. № 2. 1967. C. 252-258. \{Pugachenkova G. A. Burial of the Mongolian time in Khalchayan // Soviet archeology. No. 2. 1967. Р. 252-258.\}

Рашид ад-Дин 1952 - Рашид-ад-дин. Сборник летописей. Т. 1. Кн. 1 / Пер. с персидского Л. А. Хетагурова. М., 1952. \{Rashid ad-din. Collection of chronicles. Vol. 1. Book $1 /$ Translated from Persian by L. A. Khetagurov. Moscow, 1952.\}

Решетов 1983 - Решетов A. М. Калмыки в Средней Азии // Краткое содержание докладов Среднеазиатскокавказских чтений. Л., 1983. \{Reshetov A. M. Kalmyks in Central Asia // Summary of reports of the Central AsianCaucasian readings. Leningrad, 1983.\}

Сагидолдагийн 1993 - Сагидолдагийн Гулгайша. Казахско-монгольские топонимические параллели: автореф. дис.... канд. филол. наук. Алма-Ата, 1993. \{Sagidoldagiin Gulgaysha. Kazakh-Mongolian toponymic parallels: Summary of a PhD thesis. Alma-Ata, 1993.\}

Самарқандий 2008 - Самарқұаний Абдураззоқ. Матлаи саъдайн ва мажмаи бахрайн. II жилд, биринчи қисм. 1405-1429 йил воқеалари. Форс тилидан таржима, сўзбоши ва изохлар муаллифи А. Ўринбоев. Тошкент, 2008. \{Samarkand Abdurazzak. Matlai sadayn va mazhmai baurein. II volume, first part. Events 1405-1429, translation from Persian, introduction, and comments by A. Urinboev. Tashkent, 2008.\}

Самаркандские документы 1974 - Самаркандские документы XV-XVI вв. / Факсимиле, критический текст, перевод, введение, примечания и указатели О. Д. Чехович. М., 1974. SSamarkand documents of the $15^{\text {th }}-16^{\text {th }}$ centuries. Facsimile, critical text, translation, introduction, notes, and indexes O. D. Chekhovich. Moscow, 1974.$\}$

Санжеев 1973 - Санжеев Г. Д. О тюрко-монгольских лингвистических параллелях // Советская тюркология. 1973. № 6. C. 73-78. \{Sanzheev G. D. On the Turko-Mongolian linguistic parallels // Soviet Turkology. 1973. No. 6. P. 73-78.\}

Сборник материалов 1890 - Сборник материалов для статистики Самаркандской области за 1887-1888 годы. Вып. 1. Самарканд, 1890. \{Collection of materials for statistics of the Samarkand region for 1887-1888. Issue 1. Samarkand, 1890.\}

Скрынникова 2005 - Скрынникова Т. Д. Две Монголии: особенность средневековых идентификационных практик // Вестник Евразии № 2. 2005. С. 29-65. \{Skrynnikova T. D. Two Mongolias: the peculiarity of medieval identification practices // Bulletin of Eurasia No. 2. 2005. P. 29-65.\}

Скрынникова 2013 - Скрынникова Т. Д. Харизма и власть в эпоху Чингис-хана. СПб., 2013. \{Skrynnikova T. D. Charisma and power in the era of Genghis Khan. St. Petersburg, 2013.\}

Соболев 1874 - Соболев Л. Н. Географические и статистические сведения о Зеравшанском округе с приложением списка населенных мест округа // Записки императорского русского географического общества по отделению статистики. Т. 4. СПб., 1874. \{Sobolev L. N. Geographical and statistical information about the Zeravshan district with the attachment of a list of the inhabited places of the district // Notes of the Imperial Russian Geographical Society for the Department of Statistics. Vol. 4. St. Petersburg, 1874.\}

Солих 1989 - Солих M. Шайбонийнома. Нашрга тайёрловчи Э. Шодиев. Тошкент, 1989. \{Solih M. Shaibonynoma. Prepared for publication by E. Shodiev. Tashkent, 1989.\}

Султанов 1982 - Султанов Т. И. Кочевые племена Приаралья в XV-XVII вв. M., 1982. \{Sultanov T. I. The Aral Sea nomadic tribes in the $15^{\text {th }}-17^{\text {th }}$ centuries. Moscow, 1982.\}

Султанов 1989 - Султанов Т. И. Известия «Шейбани-наме» Мухаммада Салиха о моголах XVI в. // Страны и народы Востока. Вып. 26. М., 1989. С. 190-211. \{Sultanov T. I. Information from "Sheibani-name" of Muhammad Salikh about the Mughals of the $16^{\text {th }}$ century // Countries and peoples of the East. Issue 26. Moscow, 1989. P. 190-211.\}

Султанов 2017 - Султанов Т. И. К историографии этнополитической истории Улусов Джучи и Чагатая // Золотоордынское обозрение. Т. 5 № 1. 2017. С. 74—92. \{Sultanov T. I. Historiography of the Ethnic and Political History of the Jochid and Chaghataid Uluses. Golden Horde Review. 2017. Vol. 5. No. 1. P. $74-92$.

Сухарева 1958 - Сухарева О. А. К истории городов Бухарского ханства. Историко-этнографические очерки. Ташкент, 1958. \{Sukhareva O. A. On the history of the cities of the Bukhara Khanate. Historical and ethnographic essays. Tashkent, 1958.\}

Сухарева 1966 - Сухарева О. А. Бухара. ХІХ - начало ХХ в. (Позднефеодальный город и его население). М., 1966. \{Sukhareva O. A. Bukhara. XIX - early XX century (Late feudal city and its population). Moscow, 1966. \}

Сухарева 1976 - Сухарева O. A. Квартальная община позднефеодального города Бухары. M., 1976. \{Sukhareva O. A. Quarter community of the late feudal city of Bukhara. Moscow, 1976.\} 
Тали 1959 - Тали А. История Аблуфейзхана / Пер. с таджикского А. А. Семенова. Ташкент, 1959. \{Tali A. History of Ablufeizkhan / Translated from Tajik by A. A. Semenov. Tashkent, 1959.\}

Термези 1971 - Термези X. С. Дастур ал-мулук (Назидание государям) / Пер. с персидского, предисловие, примечания и указатели М. А. Салахетдиновой. М., 1971. \{Termezi Kh. S. Dastur al-muluk (Edification to the sovereigns) / Translation from Persian, preface, notes and indexes by M. A. Salakhetdinova. Moscow, 1971.\}

Толстова 1961a - Толстова Л. С. Материалы этнографического обследования группы «Каракалпак» Самаркандской области Узбекской ССР // Советская этнография. 1961. № 3. С. 34-44. \{Tolstova L. S. Materials of an ethnographic survey of the "Karakalpak" group of the Samarkand region of the Uzbek SSR // Soviet ethnography. 1961. No. 3. P. $34-44$.

Толстова 19616 - Толстова Л. С. Каракалпаки Бухарской области Узбекской ССР // Советская этнография. 1961. № 5. C. $44-51$ \{Tolstova L. S. Karakalpaks of the Bukhara region of the Uzbek SSR // Soviet ethnography. 1961. No. 5. P. $44-51$.

Ташев 1968 - Тамев X. Культура и быт животноводов Зарафшанской долины (конец XIX - 60-е гг. XX в.). Автореф. дисс. ... канд. ист. наук. Ташкент, 1968. \{Tashev H. Culture and everyday life of livestock breeders of the Zarafshan valley (late XIX - 60s. XX century). Author's abstract. PhD thesis. Tashkent, 1968.\}

Трепавлов 2002 - Tрепавлов В. В. История Ногайской орды. М., 2002. \{Trepavlov V. V. History of the Nogai Horde. Moscow, 2002.\}

Туйчиев 1990а - Туйчиев У. История расселения народов Узбекистана (по данным топонимии Зарафшанской долины). Автореф. дисс. ... канд. ист. наук. Ташкент, 1990. \{Tuychiev U. History of the settlement of the peoples of Uzbekistan (according to the toponymy of the Zarafshan valley). Author's abstract. PhD thesis. Tashkent, 1990.\}

Туйчиев $1990 б$ - Туйчиев У. История расселения народов Узбекистана (по данным топонимии Зарафшанской долины). Дисс. ... канд. ист. наук. Ташкент, 1990. \{Tuychiev U. History of the settlement of the peoples of Uzbekistan (according to the toponymy of the Zarafshan valley). PhD thesis. Tashkent, 1990.\}

Тураев 1989 - Тураев $X$. Документальные источники по истории феодального института танха в западной Бухаре (вторая половина XIX - начало XX вв.). Дисс. ... канд. ист. наук. Ташкент, 1989. \{Turaev H. Documentary sources on the history of the feudal institute of tanha in western Bukhara (second half of the $19^{\text {th }}$ - early $20^{\text {th }}$ centuries). $\mathrm{PhD}$ thesis. Tashkent, 1989.\}

Туробов 2002 - Туробов А. М. Самарқанд этноним ва этноойконимлари. Самарканд, 2002. \{Turobov A. M. Ethnonyms and ethnooikonyms of Samarkand. Samarkand, 2002.\}

Ўринбоев 2003 - Ц̆ринбоев Б. Асрлардек бархаёт номлар. (Самарқанд вилояти топонимлар изохи). Самарканд, 2003. \{Urinboev B. Names living in centuries. (Interpretation of toponyms of the Samarkand region). Samarkand, 2003.\}

Ўринбоев 1997 - Ўринбоев Б. Самарқанд вилояти топонимларининг изохи. Самарқанд, 1997. \{Urinboev B. Comments on toponyms of the Samarkand province. Samarkand, 1997.\}

Фитрат 2000 - Фитрат A. Танланган асарлар. 2 жилд / Нашрга тайёрловчи Х. Болтабоев. Ташкент: Маънавият, 2000. \{Fitrat A. Selected Works. 2 vol. Prepared for publication by H. Boltaboev. Tashkent, 2000.\}

Хазанов $2002-$ Хазанов А. М. Кочевники и внешний мир. Изд. 3-е, доп. Алматы, 2002. \{Khazanov A. M. №mads and the outside world. Ed. $3^{\text {rd }}$, add. Almaty, 2002.\}

Ханыков 1843 - Ханыков Н. В. Описание Бухарского ханства. СПб., 1843. С. 58 -64. \{Khanykov N. V. Description of the Bukhara Khanate. St. Petersburg, 1843. P. 58-64.\}

Хорошхин 1876 - Хорошхин А. П. Сборник статей, касающихся Туркестанского края. СПб., 1876. \{Khoroshkhin A. P. Collection of articles related to the Turkestan. St. Petersburg, 1876.\}

Цэндмаа 2013 - Цэндмаа Э. Монголизмы в «Бабур-наме» // Ученые записки Забайкальского государственного университета. Серия: Филология, история, востоковедение. 2 (49). 2013. С. 161—165. \{Tsendmaa E. Mongolisms in "Babur-name" // Scientific notes of the Trans-Baikal State University. Series: Philology, History, Oriental Studies. 2 (49). 2013. P. $161-165$.

Чехович 1965 - Чехович О.Д. Бухарские документы XIV века. Ташкент, 1965. \{Chekhovich O. D. Bukhara documents of the XIV century. Tashkent, 1965.\}

Чориев 1999 - Чориев 3. Тарих атамаларининг қисқача изохли луғати: қадимги ва ўрта асрлар. Тошкент, 1999. \{Choriev Z. A short explanatory dictionary of historical terms: antiquity and the Middle Ages. Tashkent, 1999.\}

Шомий 1996 - Шомий Низомиддин. Зафарнома / Форс тилидан угирувчи Ю. Хакимжонов. Тошкент, 1996. \{Shomiy Nizomiddin. Zafarnoma / Translated from Persian by Y. Khakimjonov. Tashkent, 1996.\}

Шониёзов 2001 - Шониёзов К. Ўзбек халқининг шаклланиш жараёни. Тошкент, 2001. \{Shoniyozov K. Sh. The process of forming the Uzbek people. Tashkent, 2001.\}

Щербак 1997 - Щербак А. М. Ранние тюрко-монгольские языковые связи (VII-XIV вв.). СПб., 1997. \{Shcherbak A. M. Early Turkic-Mongolian linguistic ties (VII-XIV centuries). St. Petersburg, 1997.\}

Юдин 2001 - Юдин В. П. Центральная Азия в XIV—XVIII веках глазами востоковеда. Алматы, 2001. \{Yudin V. P. Central Asia in the XIV-XVIII centuries through the eyes of an orientalist. Almaty, 2001.\} 
Baski 2008 - Baski Imre. Orta Asya Türk etnonimisinde kisi adlari // VI. Uluslararası Tür VI. Uluslararası Türk Dili Kurultayı Bildirileri. 20-25 Ekim 2008. 4 Cilt. Ankara, 2008.

Biran 2004 - Biran M. The Mongol Transformation: From the Steppe to Eurasian Empire // Eurasian Transformations,

Tenth to Thirteenth Centuries: Crystallizations, Divergences, Renaissance / Ed. by Johann P. Arnason and Björn Wittrock. Leiden - Boston, 2004. P. 339-361.

Biran 2005 - Biran M. The empire of the Qara Khitai in Eurasian history: between China and the Islamic World. Cambridge, 2005.

Biran 2015 - Biran M. The mongols and nomadic identity. The case of Kitans in China in Nomads as agents of cultural change. The mongols and their Eurasian predessors / Edited by Reuven Amitai and Michal Biran. Honolulu, 2015.

Burke 2003 - Burke P. Relationships among multiple identities // Advances in identity theory and research, editors:

Burke P. J., Owens T. J., Serpe R., Thoits P. A. Kluwer Academic/Plenum Publishers, 2003.

Çiçek 2015 - Çiçek S. E. Kıpçak Sözlüklerindeki Moğolca Unsurlar // Türk Dili Araştırmaları Yıllığı-Belleten 63.

2015. No. 1. P. 49-98.

Csákı 2006 - Csákı É. Middle Mongolian Loan Words in Volga Kipchak Languages. Turcologica 67. Harrassowitz Verlag, 2006.

DeWeese 1994 - DeWeese D. A. Islamization and native religion in the Golden Horde: Baba Tukles and conversion to Islam in historical and epic tradition. The Pennsylvania State University, 1994.

Golden 1992 - Golden P. B. An introduction to the history of the Turkic peoples // Ethnogenesis and state-formation in medieval and early modern Eurasia and the Middle East. Wiesbaden, 1992. P. 127-136.

Golden 2000a - Golden P. B. "I Will Give the People unto Thee": The Činggisid Conquests and Their Aftermath in the Turkic World // Journal of the Royal Asiatic Society 10. No. 1. 2000. P. $21-41$.

Golden 2000b - Golden P. B. Tatar // Encyclopaedia of Islam, Vol. X: T-U. Bearman P. J., Bianquis T., Bosworth C. E., Donzel E. van, and Heinrichs W. P. (eds). Leiden, 2000. P. 370-371.

Hesche, Hildebrandt, Thermann 1979 - Hesche W., Hildebrandt W.-D., Thermann A. Das Moгоli in Badachschan (Afghanistan) // Central Asiatic Journal 23. No. 3/4 (1979). P. 176-236.

Islamov 2020 - Islamov Z. Codicological Analysis of Manuscripts of "Mukaddamatu-1-Adab" of Mahmud Zamakhshari in the Funds of the World // The Light of Islam 2020. No. 2. 2020. P. 30-36.

Jackson 2018 - Jackson P. The Mongols of Central Asia and the Qara'unas // Iran 56, no. 1 (2018). P. 91-103.

Jenkins 1997 - Jenkins R. Rethinking ethnicity. Arguments and explorations. London and New Delhi, 1997.

Kincses-Nagy 1997 — Kincses-Nagy É. Mongolian loanwords in Chagatay // Studia Uralo-altaica. No. 39.1997.

P. $139-145$.

Lee 2016 - Lee Joo-Yup. Qazaqlïq or Ambitious Brigandage, and the Formation of the Qazaqs. State and Identity:

Post-Mongol Central Eurasia. Leiden — Boston, 2016.

Lee 2018 - Lee Joo-Yup. Some remarks on the Turkicisation of the Mongols in post-Mongol Central Asia and the Qipchaq Steppe // Acta Orientalia Academiae Scientiarum Hungaricae 71. No. 2. 2018. P. 121-144.

Malikov 2020 - Malikov A. "92 Uzbek Tribes" in Official Discourses and the Oral Traditions from the sixteenth to nineteenth centuries // Zolotoordynskoe obozrenie = Golden Horde Review. 2020. Vol. 8. No. 3. P. 515-532.

Malikov 2002 - Malikov A. Semerkant Bölgesindeki Özbeklerin Etnik Tarihi // Türkler, Cilt: VIII. 2002. P. 617 -623.

Manz 1989 - Manz B. F. The rise and rule of Tamerlane. Cambridge, 1989.

Manz 1992 - Manz B.F. The development and meaning of Chaghatay identity // Jo-Ann Gross, ed., Muslims in

Central Asia: expressions of identity and change. Durham, NC, 1992. P. $27-45$.

Matsui 2008 - Matsui D. A Mongolian decree from the Chaghataid khanate discovered at Dunhuang // Aspects of

Research into Central Asian Buddhism // In memoriam Kogi Kudara. Turnhout, 2008. P. 159_178.

May 2013 - May T. The Mongol conquests in world history. Reaktion Books, 2013.

Ölmez 2007 - Ölmez Z. Mongolian Loanwords in the Classical Chagatay Period // Festschrift in Honor of András J. E.

Bodrogligeti, Türk Dilleri Araştırmaları Dergisi 17. İstanbul, 2007. P. 229-236.

Sertkaya 1987 - Sertkaya O. F. Mongolian Words and Forms in Chagatay Turkish (Eastern Turki) and Turkey Turkish

(Western Turki) // Türk Dili Araştırmaları Yıllığı-Belleten 35, 1987. P. 265-280.

de Rachewiltz 2019 - de Rachewiltz I. The Name of the Mongols in Asia and Europe: A Reappraisal // East Asian history 43. 2019. P. 89-94.

Rossabi 2000 - Rossabi M. The Development of Mongol Identity in the Seventeenth and Eighteenth Centuries // Itinerario, 24, 2000. P. 44-61.

Saitô 2008 - Saitô Y. The Mongolian words in the Muqaddimat al-Adab: romanized text and word index. Tokyo, 2008.

Şiban (Han.), Karasoy 1998 - Şiban (Han.) Karasoy Y. Şiban Han dîvânı: (inceleme-metin-dizin-tıpkıbasım). Türk Dil Kurumu, 1998.

Togan - Togan A. Zeki Velidi. The Composition of the History of the Mongols by Rashīd al-Dīn // Central Asiatic Journal. Vol. 7. No 1. 1962. P. 60-72. 
Vovin 2019 - Vovin A. A sketch of the earliest Mongolic language: The Brāhmī Bugut and Khüis Tolgoi inscriptions // International Journal of Eurasian Linguistics 1. No. 1 2019. P. 162-197.

Weiers 1972. - Weiers M. Die Sprache der Moghol der Provinz Herat in Afghanistan. Sprachmaterial, Grammatik, Wortliste. Vol. 49. Opladen, 1972.

Wing 2016 - Wing P. Tribes and the Chinggisid Empire // The Jalayirids: Dynastic State Formation in the Mongol Middle East. Edinburgh, 2016. P., 29—47.

Zsidai 2018 - Zsidai Zs. Some Thoughts on the Translation and Interpretation of Terms Describing Turkic Peoples in Medieval Arabic Sources // The Hungarian Historical Review 7. No. 1. 2018. P. 57-81. 